\title{
Dissecting Foreign Bank Lending Behavior During the 2008-2009 Crisis
}

\author{
Moon Jung Choi* \\ Eva Gutierrez** \\ Maria Soledad Martinez Peria***
}

The views expressed herein are those of the authors and do not necessarily reflect the official views of the Bank of Korea. When reporting or citing this paper, the authors' names should always be explicitly stated.

* Economist, Economic Research Institute, the Bank of Korea, 39, Namdaemunno, Jung-Gu, Seoul, 100-794, Republic of Korea, Email: mjchoi@bok.or.kr

** Lead Financial Sector Specialist, Finance and Private Sector Development, the World Bank, 1818 H St. N.W., Washington, D.C. 20433, Email: egutierrez2@worldbank.org

*** Research Manager, Finance and Private Sector Development Research Group, the World Bank, 1818 H St. N.W., Washington, D.C. 20433, E-mail: mmartinezperia@worldbank.org

The authors thank participants at a seminar organized by the World Bank Finance and Private Sector Development unit for Latin America for comments and suggestions, as well as participants at seminars at Murcia University (Spain) and the Korea International Economic Association Annual Meeting. We are especially grateful to Roberto Rocha for the very useful feedback he provided at various stages of our research. We also thank Neeltje van Horen and Stijn Claessens for sharing data with us. The opinions expressed in this paper are those of the authors and do not represent the views of the Bank of Korea or the World Bank. Corresponding author: Maria Soledad Martinez Peria, The World Bank, 1818 H St. N.W., Washington, D.C. 20433. MSN-MC 3-307. mmartinezperia@worldbank.org. All remaining errors are our own. 


\section{Contents}

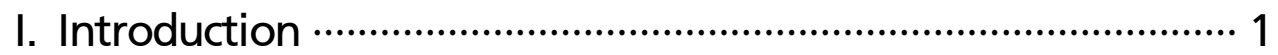

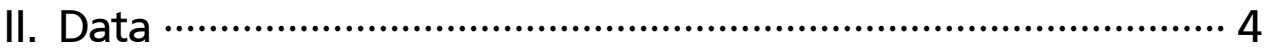

III. Empirical Methodology ……........................................... 8

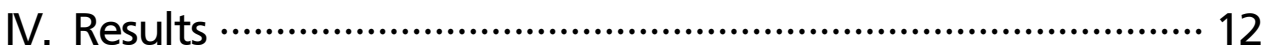

V. Conclusions and Policy Recommendations ….................... 24

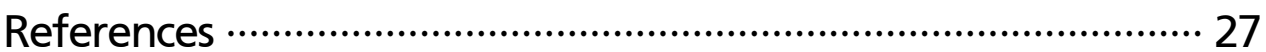

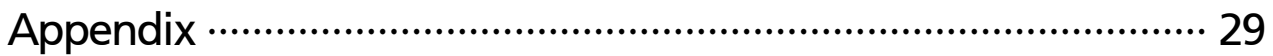




\section{Dissecting Foreign Bank Lending Behavior During the 2008-2009 Crisis}

This paper analyzes the lending behavior of foreign-owned banks during the recent global crisis. Using bank-level panel data for countries in Central and Eastern Europe, East Asia, and Latin America, the paper explores the role of affiliate and parent financial characteristics, host location, as well as the impact of parent geographic origin and reach on foreign banks' credit growth.

Overall, the analysis finds robust evidence that foreign banks curtailed the growth of credit relative to other banks, independent of the host region. Foreign bank affiliates from the United States reduced loan growth less than those from other regions. The lending growth of foreign affiliates does not depend on whether their parent banks are global or regional banks. However, the funding structure of foreign bank affiliates and the capitalization of parent banks do help explain the lending behavior of foreign affiliates during the global crisis. Although not the focus of the paper, it also finds that government-owned banks played a countercyclical role in all regions.

Keywords: foreign banks, financial globalization, bank lending, crisis

JEL Classification: F21, F23, F65, G21 


\section{Introduction}

Between 1999 and 2009, the average share of bank assets held by foreign banks in developing countries rose from 26 percent to 46 percent. ${ }^{1)}$ This significant transformation in bank ownership spurred a large literature looking at the consequences of foreign bank entry. For the most part, studies have found that foreign bank participation brought many benefits to developing countries, especially in terms of competition and banking sector efficiency.2) Furthermore, research on the behavior of foreign banks during host country-grown crisis episodes, such as the Tequila 1994 crisis and the 1997 Asian crisis, indicate that foreign banks can have a stabilizing impact on the supply of credit in developing countries (Peek et al., 2000; Crystal et al., 2001, 2002; De Haas and van Lelyveld, 2006; Detragiache and Gupta, 2006). In particular, because foreign banks typically operate in many countries they can allocate liquidity and capital from their headquarters or from affiliates outside the afflicted host country to help stabilize local credit during host-grown crises.

The recent global crisis has reignited interest in studying the behavior of foreign banks in developing countries during periods of financial turmoil. In particular, the fact that the 2008-2009 crisis was a home-grown as opposed to a host-grown episode makes it an interesting case to analyze, since it creates the potential for foreign banks to transmit the shocks they suffer in their home countries to their affiliates overseas. $^{3)}$

Using bank-level panel data for countries in Central and Eastern Europe, East Asia, and Latin America, this paper analyzes the lending behavior of foreign banks during the recent global crisis. In particular, we explore the role of affiliate and parent financial characteristics (such size, solvency, liquidity, and funding structure), affiliate location, as well as the impact of parent origin (US, European or Asian)

1) These data come from the World Bank Regulation and Supervision Surveys. See http:/ /econ.worldbank.org/ WBSITE/EXTERNAL/EXTDEC/EXTRESEARCH/0,,contentMDK:20345037 pagePK:64214825 piPK : 64214943 theSitePK:469382,00.html.

2) See Cull and Martinez Peria (2011) for a review of the literature on the drivers and the impact of foreign bank participation.

3) Previous studies of earlier crises such as the Japanese crisis (Peek and Rosengren, 2000) and the Russian crisis (Schnabl, 2012) in the 1990s offer evidence of how shocks to parent banks can be transmitted to their foreign affiliates, negatively impacting their lending behavior. 
and geographic reach (global or regional) on foreign banks' credit growth.

We find robust evidence that foreign banks curtailed the growth of credit relative to other banks, independently of what host region we focus on. US banks reduced loan growth less than other parent banks. Neither the global nor regional reach of parent banks (i.e., whether the parent bank operated in one or more regions) influenced the lending growth of foreign affiliates. On the other hand, foreign affiliates of well-capitalized parents experienced a significantly smaller decline in loan growth. Reliance on wholesale funding prompted more credit growth retrenchment by foreign banks, but only among those whose parents were non-financial institutions. This result suggests that wholesale funding is more volatile than parent funding. Albeit not the focus of our paper, our estimations also indicate that government-owned banks played a countercyclical role during the crisis, growing their loan portfolio faster than privately owned institutions.

Our paper is related to the rapidly growing literature providing evidence that foreign banks were conduits for the global propagation of the recent crisis. One strand of this literature has looked at how the crisis affected cross-border bank lending (i.e., direct lending from foreign banks outside a country to firms or consumers in the country). Within this strand of the literature, some studies have used aggregate country-level data collected by the Bank for International Settlements on foreign bank and cross-border bank claims (e.g., McGuire and Tarashev, 2008; Herrmann and Mihaljeck, 2010; Cetorelli and Golberg, 2011), while others have used syndicated loan market data to show how cross-border lending was impacted by the crisis (e.g., De Haas and van Horen 2012, 2013 and Giannetti and Laeven, 2012).

A second, and much more closely related, strand of the literature focuses on how the crisis affected lending by foreign bank affiliates in emerging markets. For example, using a bank-level panel data set for banks in emerging Europe, De Haas et al. (2012) show that foreign bank affiliates reduced their lending earlier and faster than domestic banks in the region. Fungácová et al. (2013) find a similar result for Russia. Using also bank-level data, Cull and Martinez Peria (2013) compare the behavior of foreign vis-a-vis domestic banks in eight Eastern European and six Latin American countries. The authors find that while foreign banks clearly reduced their lending more than domestic banks in Eastern Europe, the differences 
were much less pronounced and robust in the case of Latin America.

Our paper is most closely related to Claessens and van Horen (2013). Using a database including 3,615 banks (of which 1,198 are foreign) operating in 118 countries, the authors compare lending growth by foreign banks relative to domestic banks (without distinguishing between private and government-owned banks) during 2005-2009. They find that foreign banks reduced loan growth more than domestic banks during 2009. However, they provide some evidence of heterogeneity across foreign banks. In particular, they find that foreign banks that funded their operations from local deposits reduced their lending less during the global crisis. Though Claessens and van Horen (2013) provide substantial evidence regarding the behavior of foreign banks during the recent global crisis, they ignore important questions such as: Are the findings that foreign banks contract lending more than domestic banks during the crisis driven by the behavior of government-owned banks or do these results survive when comparing foreign banks to domestic private banks?4) Are there any differences in the behavior of foreign banks across host regions? Are there other affiliate characteristics besides funding structure that affect the extent to which foreign banks reacted to the crisis relative to domestic banks? Does the country of origin or financial health of the parent influence the extent to which foreign affiliates respond to the crisis? Do global banks (those with operations in more than one region) behave differently than regional foreign banks, which mainly operate within their own region?

Some of these questions - most notably the role of affiliate and parent characteristics in explaining foreign bank behavior - are tackled by De Haas and van Lelyveld (2013), in a recent study examining the growth of credit for 199 foreign affiliates operating in 53 countries vis-a-vis the behavior of the top five domestic banks in these countries (202 banks in total). The authors find that the funding structure of the affiliates and the parent impacted the growth of foreign bank lending. Affiliates that relied on wholesale funds directly or whose parent adopted a wholesale funding model reduced lending more significantly during the global crisis.

Our study reexamines the role of affiliate and parent characteristics in explaining

4) In their analyses, De Haas et al. (2012) and Cull and Martinez Peria (2013) separate government-owned from privately-owned domestic banks, but their sample of countries is much smaller than ours. 
the behavior of foreign banks, using a sample of banks that is twice as large as that of De Haas and Lelyveld (2013). Furthermore, we consider some unexplored issues such as the impact of parent origin (US, European or Asian) and geographic reach (global or regional) on foreign banks' credit growth, while accounting for the behavior of government-owned banks. Overall, we believe that our paper delivers a more comprehensive and nuanced analysis of the behavior of foreign banks in the context of the global crisis.

The rest of the paper is organized as follows. Section II discusses the data. Section III lays out the empirical methodology. Section IV presents the empirical results. Section V concludes.

\section{Data}

Our database combines annual bank-level financial information from Bankscope, a commercial dataset provided by Bureau van Dijk, with bank ownership information collected from various sources including Fitch Research, The Bankers' Almanac, bank websites, Central Bank publications, parent company's reports and bank regulation authorities. Overall, our dataset covers 1,194 banks ${ }^{5)}$ operating in 51 countries from 2005 to 2009. Our sample spans three regions, including 7 countries in East Asia and the Pacific (EAP), 25 in Europe and Central Asia (ECA), and 19 in Latin America and the Caribbean (LAC). Because ECA is the largest and most diverse region in terms of the number of countries, we further divide the region into three sub-groups: 5 countries that participated in the so-called "Vienna Initiative" (ECA VI), ${ }^{6)} 8$ countries that were part of the former Soviet Union (ECA

5) Our data set includes the following 4 types of banks based on specialization codes classified by Bankscope: commercial banks, savings banks, cooperative banks, and government specialized credit institutions.

6) The Vienna Initiative was an action plan in which multinational banks, international financial institutions (EBRD, IMF, World Bank), and European governments agreed to cooperate to support the local banking systems in Bosnia, Hungary, Latvia, Serbia, and Romania. The international financial institutions provided support in exchange for countries' commitments to keep their economic programs on track. In turn, various multinational banks (Alpha Bank, Bayerische Landesbank, Erste Group, Eurobank EFG, 
FSU), and 12 countries that constitute the rest of Eastern Europe (ECA Europe). Table 1 lists the countries included in our sample and in each of the regions and sub-regions.

We classify banks into three ownership categories: foreign, domestic private, and domestic government-owned banks. A bank is defined as a foreign bank if 50 percent or more of the bank shares are owned by foreigners. Similarly, a bank is classified as a domestic government-owned bank if 50 percent or more of its shares are owned by local or central governments. All remaining banks are classified as domestic private banks.7)

Table 1 presents regional level shares of banks by ownership type for each year in terms of both the number of banks and total assets. East Asia shows the lowest foreign bank presence with $12.7 \%$ of assets held by foreign banks in 2009. In contrast, Europe and Central Asia shows the highest level of foreign presence with foreign banks accounting for more than $52 \%$ of assets throughout the sample period. However, ECA FSU shows a very different composition of banks by ownership type compared to the other ECA sub-groups. The asset share of foreign banks in ECA FSU (at most $33.6 \%$ ) is significantly lower than that of the ECA average (greater than 52.4\%).

Among the foreign banks, we identify the parent banks and classify them using different criteria. First, we divide foreign banks into global and regional banks depending on whether the parent operates across different regions or mostly within its home region. Those parent institutions operating internationally outside of their own home region, such as CITI and HSBC, are defined as foreign global groups (FGG). Second, we categorize foreign banks by their parent's country of origin depending on whether the parent is based in Europe, the US, or other region.

Hype Alpe-Adria, ING, Intesa San Paolo, KBC Group, National Bank of Greece, Nordea Bank, OTP, Piraeus Bank, Raiffeisen International, Skandinaviska Enskilda Banker, Societe Generale, Swedbank, UniCredit, and Volksbank) signed commitment letters in which they pledged to maintain exposures and keep their affiliates in these countries adequately capitalized.

7) We cross-checked our ownership data with the database constructed by Claessens and van Horen (2013), which provides information on whether the bank is domestic or foreign along with country of parent. While Claessens and van Horen (2013) determine the ownership based on direct ownership, we focus on ultimate ownership. This different definition results in discrepancy in ownership or parent countries in approximately $5 \%$ of observations of our data. However, our regression results replicating the Claessens and van Horen (2013) analysis produce consistent results with theirs, indicating that it does not significantly affect the results. 
Table 1: Shares of Banks by Ownership Type

\begin{tabular}{|c|c|c|c|c|c|c|c|c|c|c|c|c|}
\hline \multirow{2}{*}{ Region } & \multirow{2}{*}{\multicolumn{2}{|c|}{ Ownership }} & \multicolumn{5}{|c|}{ Shares in Number of Banks } & \multicolumn{5}{|c|}{ Shares in Total Assets } \\
\hline & & & 2005 & 2006 & 2007 & 2008 & 2009 & 2005 & 2006 & 2007 & 2008 & 2009 \\
\hline \multirow{9}{*}{$\begin{array}{l}\text { EAP } \\
\text { Cambodia, } \\
\text { Indonesia, } \\
\text { South Korea, } \\
\text { Malaysia, } \\
\text { Philippines, } \\
\text { Thailand, } \\
\text { Vietnam }\end{array}$} & \multicolumn{2}{|c|}{$\begin{array}{c}\text { Total Number of } \\
\text { Banks }\end{array}$} & 142 & 174 & 184 & 191 & 181 & & & & & \\
\hline & \multicolumn{2}{|c|}{ Domestic Public (\%) } & 23.2 & 21.8 & 21.7 & 21.5 & 21.0 & 36.2 & 36.5 & 33.5 & 33.5 & 33.3 \\
\hline & \multicolumn{2}{|c|}{ Domestic Private (\%) } & 48.6 & 51.7 & 51.1 & 51.3 & 52.5 & 48.4 & 49.2 & 54.1 & 53.2 & 54.0 \\
\hline & \multicolumn{2}{|c|}{ Foreign (\%) } & 28.2 & 26.4 & 27.2 & 27.2 & 26.5 & 15.4 & 14.3 & 12.4 & 13.3 & 12.7 \\
\hline & \multirow{5}{*}{$\begin{array}{l}\text { Sub- } \\
\text { groups } \\
\text { of } \\
\text { Foreign } \\
(\%)\end{array}$} & Global & 9.2 & 8.6 & 8.2 & 7.9 & 7.7 & 8.9 & 8.0 & 6.5 & 7.0 & 6.3 \\
\hline & & Regional & 19.0 & 17.8 & 19.0 & 19.4 & 18.8 & 6.5 & 6.3 & 5.9 & 6.4 & 6.4 \\
\hline & & EU origin & 4.9 & 5.2 & 6.0 & 5.2 & 5.5 & 5.3 & 4.8 & 3.9 & 4.1 & 3.9 \\
\hline & & US origin & 3.5 & 2.9 & 2.7 & 3.1 & 2.8 & 7.5 & 6.8 & 5.9 & 6.1 & 5.4 \\
\hline & & Other origin & 19.7 & 18.4 & 18.5 & 18.8 & 18.2 & 2.6 & 2.8 & 2.5 & 3.1 & 3.3 \\
\hline \multirow{9}{*}{$\begin{array}{c}\text { LAC } \\
\text { Argentina, } \\
\text { Bolivia, Brazil, } \\
\text { Chile } \\
\text { Colombia, } \\
\text { Costa Rica, } \\
\text { Dominican Rep., } \\
\text { Ecuador, } \\
\text { El Salvador, } \\
\text { Guatemala, } \\
\text { Honduras, } \\
\text { Jamaica, } \\
\text { Mexico, } \\
\text { Nicaragua, } \\
\text { Panama, } \\
\text { Paraguay, } \\
\text { Peru, } \\
\text { Uruguay, } \\
\text { Venezuela }\end{array}$} & \multicolumn{2}{|c|}{$\begin{array}{l}\text { Total Number of } \\
\text { Banks }\end{array}$} & 411 & 423 & 468 & 467 & 436 & & & & & \\
\hline & \multicolumn{2}{|c|}{ Domestic Public (\%) } & 12.4 & 11.1 & 10.5 & 10.9 & 11.2 & 39.8 & 34.8 & 28.9 & 20.1 & 25.8 \\
\hline & \multicolumn{2}{|c|}{ Domestic Private (\%) } & 55.7 & 55.6 & 52.4 & 52.2 & 51.1 & 34.8 & 37.3 & 43.2 & 43.8 & 48.3 \\
\hline & \multicolumn{2}{|c|}{ Foreign (\%) } & 31.9 & 33.3 & 37.2 & 36.8 & 37.6 & 25.5 & 27.9 & 27.9 & 36.1 & 25.9 \\
\hline & \multirow{5}{*}{$\begin{array}{l}\text { Sub- } \\
\text { groups } \\
\text { of } \\
\text { Foreign } \\
(\%)\end{array}$} & Global & 13.9 & 14.9 & 18.4 & 18.2 & 18.8 & 21.1 & 24.0 & 24.6 & 32.7 & 22.6 \\
\hline & & Regional & 18.0 & 18.4 & 18.8 & 18.6 & 18.8 & 4.3 & 3.9 & 3.3 & 3.4 & 3.3 \\
\hline & & EU origin & 10.9 & 11.3 & 12.6 & 13.7 & 13.3 & 17.7 & 20.7 & 21.2 & 26.3 & 16.1 \\
\hline & & US origin & 5.4 & 5.4 & 7.1 & 5.8 & 6.9 & 3.2 & 2.7 & 2.6 & 5.8 & 6.4 \\
\hline & & Other origin & 15.6 & 16.5 & 17.5 & 17.3 & 17.4 & 4.6 & 4.4 & 4.1 & 4.0 & 3.4 \\
\hline \multirow{9}{*}{ ECA } & \multicolumn{2}{|c|}{$\begin{array}{c}\text { Total Number of } \\
\text { Banks }\end{array}$} & 351 & 409 & 444 & 458 & 431 & & & & & \\
\hline & \multicolumn{2}{|c|}{ Domestic Public (\%) } & 10.5 & 8.8 & 8.1 & 9.0 & 10.0 & 16.7 & 12.5 & 15.6 & 16.1 & 18.8 \\
\hline & \multicolumn{2}{|c|}{ Domestic Private (\%) } & 41.3 & 37.9 & 33.1 & 30.3 & 29.7 & 30.9 & 27.7 & 29.1 & 26.9 & 27.0 \\
\hline & \multicolumn{2}{|c|}{ Foreign (\%) } & 48.1 & 53.3 & 58.8 & 60.7 & 60.3 & 52.4 & 59.8 & 55.3 & 57.1 & 54.3 \\
\hline & \multirow{5}{*}{$\begin{array}{c}\text { Sub- } \\
\text { groups } \\
\text { of } \\
\text { Foreign } \\
(\%)\end{array}$} & Global & 11.1 & 12.7 & 13.7 & 14.2 & 14.6 & 17.5 & 17.6 & 16.1 & 17.1 & 16.6 \\
\hline & & Regional & 37.0 & 40.6 & 45.0 & 46.5 & 45.7 & 34.9 & 42.2 & 39.2 & 40.0 & 37.6 \\
\hline & & EU origin & 42.2 & 46.9 & 52.5 & 54.4 & 54.3 & 47.9 & 55.6 & 51.1 & 52.4 & 50.4 \\
\hline & & US origin & 3.4 & 3.7 & 3.4 & 3.3 & 2.8 & 4.2 & 3.9 & 3.2 & 3.5 & 2.7 \\
\hline & & Other origin & 2.6 & 2.7 & 2.9 & 3.1 & 3.2 & 0.2 & 0.2 & 1.0 & 1.2 & 1.2 \\
\hline \multirow{9}{*}{$\begin{array}{c}\frac{\text { ECA }}{\text { VI }} \\
\text { Bosnia and } \\
\text { Herzegovina, } \\
\text { Hungary, } \\
\text { Latvia, } \\
\text { Romania, } \\
\text { Serbia }\end{array}$} & \multicolumn{2}{|c|}{$\begin{array}{c}\text { Total Number of } \\
\text { Banks }\end{array}$} & 98 & 107 & 112 & 108 & 100 & & & & & \\
\hline & Domest & c Public (\%) & 9.2 & 6.5 & 5.4 & 8.3 & 10.0 & 14.9 & 5.3 & 2.6 & 6.8 & 7.6 \\
\hline & Domesti & Private (\%) & 28.6 & 28.0 & 21.4 & 18.5 & 19.0 & 23.3 & 20.7 & 19.6 & 16.2 & 18.7 \\
\hline & For & eign (\%) & 62.2 & 65.4 & 73.2 & 73.1 & 71.0 & 61.9 & 74.0 & 77.7 & 76.9 & 73.7 \\
\hline & & Global & 15.3 & 15.0 & 14.3 & 13.9 & 13.0 & 19.5 & 18.2 & 18.2 & 17.3 & 14.6 \\
\hline & Sub- & Regional & 46.9 & 50.5 & 58.9 & 59.3 & 58.0 & 42.4 & 55.9 & 59.5 & 59.7 & 59.1 \\
\hline & of & EU origin & 54.1 & 57.9 & 66.1 & 65.7 & 65.0 & 56.8 & 69.8 & 73.7 & 72.9 & 71.5 \\
\hline & $\begin{array}{c}\text { Foreign } \\
\text { (\%) }\end{array}$ & US origin & 3.1 & 2.8 & 3.6 & 4.6 & 3.0 & 4.5 & 3.8 & 3.5 & 3.6 & 1.8 \\
\hline & & Other origin & 5.1 & 4.7 & 3.6 & 2.8 & 3.0 & 0.6 & 0.5 & 0.5 & 0.4 & 0.4 \\
\hline
\end{tabular}




\begin{tabular}{|c|c|c|c|c|c|c|c|c|c|c|c|c|}
\hline \multirow[b]{2}{*}{ Region } & & & & ares in & Numbe & of $\mathrm{Ba}$ & & & Shares & in Tote & Assets & \\
\hline & \multicolumn{2}{|c|}{ Ownership } & 2005 & 2006 & 2007 & 2008 & 2009 & 2005 & 2006 & 2007 & 2008 & 2009 \\
\hline \multirow{9}{*}{$\begin{array}{l}\underline{\text { ECA }} \\
\text { FSU } \\
\text { Armenia, } \\
\text { zerbaijan, } \\
\text { Belarus, } \\
\text { Georgia, } \\
\text { zakhstan, } \\
\text { Moldova, } \\
\text { Jkraine, } \\
\text { zbekistan }\end{array}$} & \multicolumn{2}{|c|}{$\begin{array}{c}\text { Total Number of } \\
\text { Banks }\end{array}$} & 111 & 128 & 140 & 149 & 140 & & & & & \\
\hline & \multicolumn{2}{|c|}{ Domestic Public (\%) } & 12.6 & 10.9 & 10.7 & 11.4 & 12.9 & 19.9 & 15.8 & 14.5 & 21.5 & 28.2 \\
\hline & \multicolumn{2}{|c|}{ Domestic Private (\%) } & 59.5 & 57.0 & 50.0 & 43.6 & 39.3 & 69.8 & 69.7 & 64.5 & 48.7 & 38.1 \\
\hline & \multicolumn{2}{|c|}{ Foreign (\%) } & 27.9 & 32.0 & 39.3 & 45.0 & 47.9 & 10.3 & 14.5 & 21.0 & 29.8 & 33.6 \\
\hline & \multirow{5}{*}{$\begin{array}{c}\text { Sub- } \\
\text { groups } \\
\text { of } \\
\text { Foreign } \\
(\%)\end{array}$} & Global & 5.4 & 7.0 & 7.9 & 9.4 & 9.3 & 2.5 & 5.8 & 6.1 & 7.8 & 7.9 \\
\hline & & Regional & 22.5 & 25.0 & 31.4 & 35.6 & 38.6 & 7.9 & 8.8 & 14.9 & 22.1 & 25.8 \\
\hline & & EU origin & 22.5 & 25.8 & 32.9 & 38.3 & 40.0 & 9.2 & 13.1 & 19.2 & 28.6 & 31.3 \\
\hline & & US origin & 2.7 & 3.1 & 2.9 & 2.0 & 2.1 & 0.9 & 1.1 & 1.6 & 0.7 & 1.0 \\
\hline & & Other origin & 2.7 & 3.1 & 3.6 & 4.7 & 5.7 & 0.3 & 0.3 & 0.3 & 0.5 & 1.3 \\
\hline$\frac{\text { ECA }}{\text { Europe }}$ & \multicolumn{2}{|c|}{$\begin{array}{l}\text { Total Number of } \\
\text { Banks }\end{array}$} & 142 & 174 & 192 & 201 & 191 & & & & & \\
\hline Bulgaria, & \multicolumn{2}{|c|}{ Domestic Public (\%) } & 9.9 & 8.6 & 7.8 & 7.5 & 7.9 & 16.7 & 14.1 & 19.2 & 17.4 & 20.0 \\
\hline Croatia, & \multicolumn{2}{|c|}{ Domestic Private (\%) } & 35.9 & 29.9 & 27.6 & 26.9 & 28.3 & 25.9 & 20.3 & 24.5 & 25.4 & 27.3 \\
\hline Republic, & \multicolumn{2}{|c|}{ Foreign (\%) } & 54.2 & 61.5 & 64.6 & 65.7 & 63.9 & 57.4 & 65.6 & 56.2 & 57.2 & 52.7 \\
\hline onia, & \multirow{5}{*}{$\begin{array}{c}\text { Sub- } \\
\text { groups } \\
\text { of } \\
\text { Foreign } \\
(\%)\end{array}$} & Global & 12.7 & 15.5 & 17.7 & 17.9 & 19.4 & 19.8 & 20.2 & 17.6 & 18.9 & 18.5 \\
\hline Macedonia, & & Regional & 41.5 & 46.0 & 46.9 & 47.8 & 44.5 & 37.7 & 45.4 & 38.6 & 38.3 & 34.3 \\
\hline $\begin{array}{l}\text { Montenegro, } \\
\text { Poland, }\end{array}$ & & EU origin & 49.3 & 55.7 & 58.9 & 60.2 & 59.2 & 52.5 & 60.8 & 51.4 & 51.7 & 48.2 \\
\hline $\begin{array}{l}\text { Slovakia, } \\
\text { Slovenia }\end{array}$ & & US origin & 4.2 & 4.6 & 3.6 & 3.5 & 3.1 & 4.8 & 4.6 & 3.4 & 4.0 & 3.1 \\
\hline Turkey & & Other origin & 0.7 & 1.1 & 2.1 & 2.0 & 1.6 & 0.1 & 0.2 & 1.3 & 1.5 & 1.4 \\
\hline
\end{tabular}

Notes: This table presents the distribution of banks by their ownership type in terms of their asset shares and number of banks across regions in our sample. It also lists the countries in the sample within each region. Foreign banks are further categorized according to their parent reach (global or regional) and parent origin (EU, US, or other origin).

Appendix Table A.1 shows the list of parent institutions in our sample, along with the information on these two classifications.

Shares of sub-groups of foreign banks are also reported in Table 1. Foreign global banks are more dominant in Latin America, both in terms of numbers and asset share, while foreign regional banks are relatively more common in Eastern Europe. In terms of parent origin, European banks dominate in Latin America and Eastern Europe.

From Bankscope, we collect each bank's financial information on gross loans, asset size, capitalization, liquidity, and funding structure. ${ }^{8)}$ We also collect financial 
information for the parents of foreign banks from Bankscope based on the ownership information constructed in our data set.9) Similarly to affiliate characteristics, the parent variables we gather data on include: size, equity ratio, liquidity ratio, and deposit funding ratio.

Figure 1 shows that the growth of credit fell across all bank ownership types and regions during 2008 and, in particular, during 2009, at the height of the global financial crisis. However, it appears from this figure and from Figure 2 that the drop in credit was most significant for foreign relative to domestic banks. These graphs do not control for any other bank characteristics that might be driving these results. Hence, in the next section, we explain the estimations we undertake to dissect the behavior of foreign banks relative to other banks during the crisis.

\section{Empirical Methodology}

Our baseline specification to analyze bank lending behavior follows equation (1) below:

$$
\begin{gathered}
\Delta L_{i, j, t}=\mu_{i}+\alpha_{j t}+\text { Crisis_2008 } 8_{t} \times \text { Foreign }_{i, j}+\text { Crisis_2009 }{ }_{t} \times \text { Foreign }_{i, j} \\
+ \text { Crisis_2008 }{ }_{t} \times X_{i, j}+\text { Crisis_2009 }{ }_{t} \times X_{i, j}+u_{i, j, t}
\end{gathered}
$$

where $\Delta L_{i, j, t}$ is the real growth of total gross loans calculated as the log difference in real gross loans of bank $i$ in country $j$ in year $t . \mu_{i}$ are bank fixed effects that capture non-changing bank characteristics and $\alpha_{j t}$ represent country-time dummies intended to control for country specific macro effects that might influence bank lending (e.g., the growth of GDP). Foreign is a dummy that takes the value of one for foreign-owned banks. Crisis_2008 and Crisis_2009 are dummies that equal

8) Variables with nominal values are converted into real terms using the consumer price index for the US. Gross loans and total assets in million US dollars are divided by the US consumer price index (2005=100) from the IMF's International Financial Statistics.

9) Since financial information for non-financial institutions is not available in Bankscope, parents' financial data is missing for those foreign banks with non-financial institutions as their foreign parents. 
Figure 1: The Average Credit Growth of banks by ownership type across regions

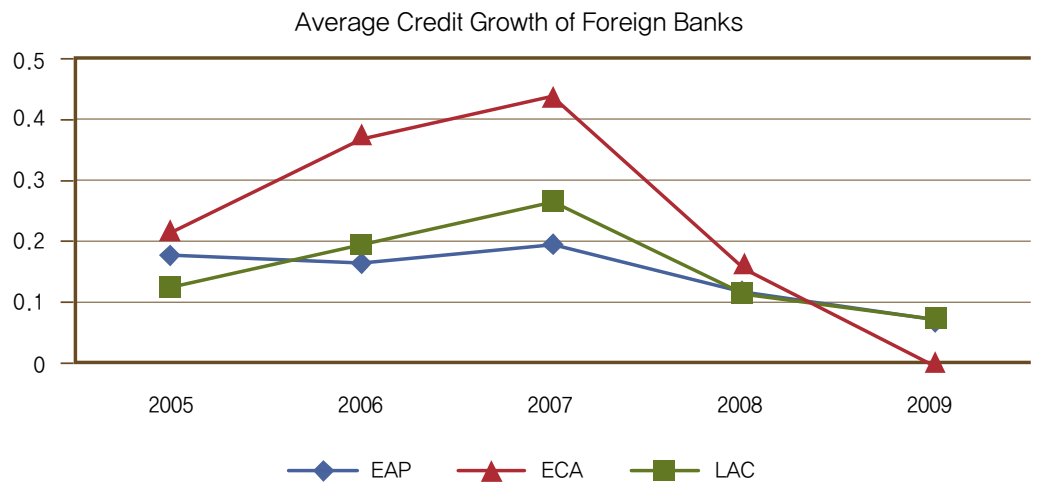

Average Credit Growth of Domestic Public Banks

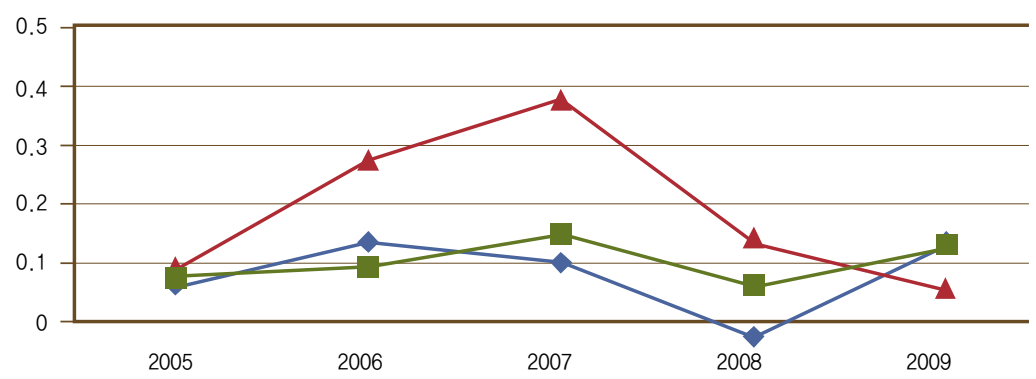

Average Credit Growth of Domestic Private Banks

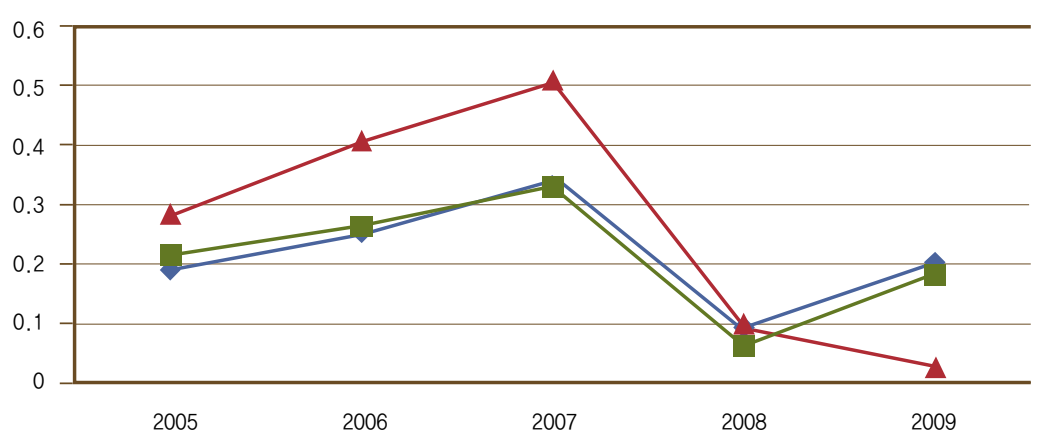

Notes: These figures show the average annual credit growth of banks by their ownership type across regions. EAP stands for East Asia and Pacific region, ECA means Europe and Central Asia region, and LAC is Latin America and the Caribbean region. 
Figure 2: Differences in credit across ownership bank types

Credit Growth Difference : Foreign - Domestic

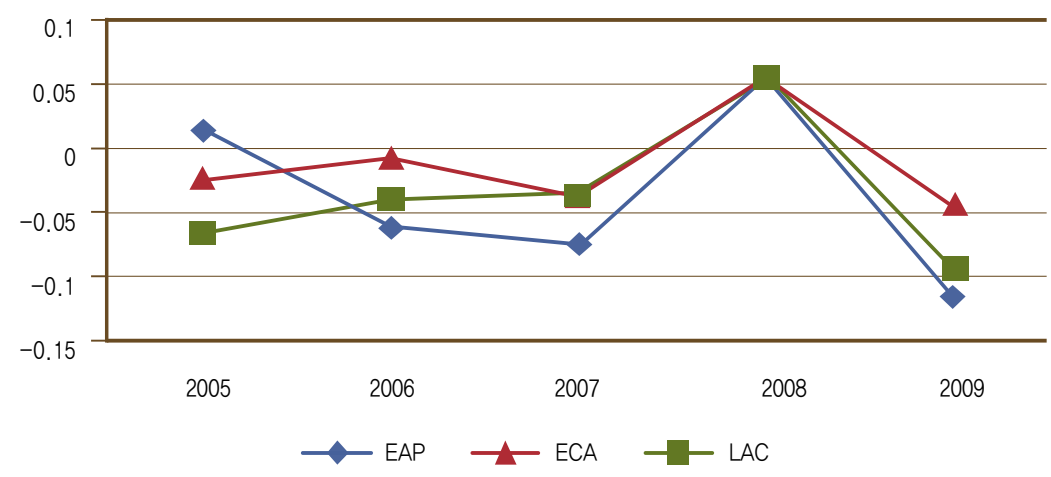

Credit Growth Difference : Foreign - Domestic Private

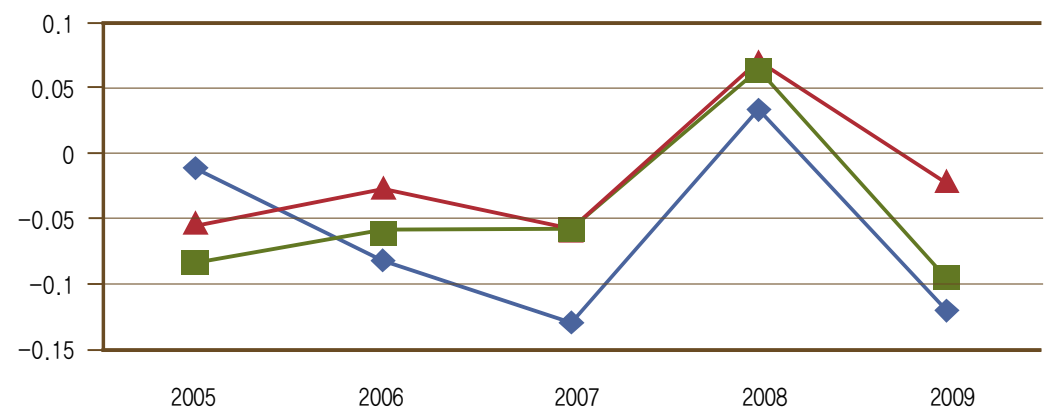

Notes: The upper panel of Figure 2 shows the regional average credit growth difference between foreign banks and domestic (private and public) banks. The lower panel of Figure 2 shows the average credit growth difference between foreign banks and domestic private banks of banks across regions. EAP stands for East Asia and Pacific region, ECA means Europe and Central Asia region, and LAC is Latin America and the Caribbean region. 
one during 2008 and 2009, respectively. Both dummies are zero in all other periods. The interactions of Foreign with the crisis dummies capture the impact of foreign bank ownership during the crisis, relative to the lending behavior of domestic banks throughout this episode. $X_{i, j}$ is a matrix of bank characteristics that can also impact loan growth (such as size, capital, liquidity, and funding structure) averaged over the period 2007-2008. To exclude outliers from the data set, we drop the observations of the dependent variable below the bottom $1 \%$ and above top $1 \%$. We also drop observations with negative equity ratios.

We estimate a number of variants of equation (1). First, to examine whether the findings on the lending behavior of foreign banks depend on whether we compare them to domestic banks in general or only to the subset of private banks, we estimate a version of equation (1) where we include a dummy for governmentowned banks interacted with the crisis dummies in the same way as we do with the foreign-owned dummy.

Second, to analyze differences in the behavior of foreign and government- owned banks depending on the region in which they operate, we add triple interactions of ownership, crisis, and regional dummies. In particular, we treat countries in Latin America as the base category and we include interaction dummies for countries in East Asia and for the different sub-groups of countries in Eastern Europe and Central Asia: those that participated in the Vienna Initiative, those that are Former Soviet Union countries, which have experienced lower foreign bank entry, and countries in the rest of Eastern Europe.

Third, to study whether bank characteristics other than funding structure affect the extent to which foreign banks react to the crisis relative to domestic banks, we conduct estimations where we include triple interactions of Foreign, the crisis dummies, and each of the variables in $X_{i, j}$. These estimations allow us to assess whether foreign banks with different balance sheet structure (e.g., bigger in terms of assets, better capitalized, or more liquid) respond differently to the crisis.

Fourth, to assess the extent to which the relative importance of foreign affiliates within a foreign parent group impact the lending behavior of foreign banks, we construct two measures of affiliate importance: the share of affiliate to parent assets and the share of affiliate to parent profits. We interact these measures with our 
ForeignxCrisis dummies to ascertain whether affiliate importance influences the extent to which foreign bank lending responds to the crisis.

Fifth, to analyze whether global banks (those with operations in more than one region) behave differently than regional foreign banks (who operate within their own region) and to assess differences in the behavior of foreign banks based on their country of origin, we conduct estimations including interactions of Foreign with a dummy for regional banks and, separately, including interactions of Foreign with dummies for banks from Europe and from the US, respectively.

Finally, we also conduct estimations to explore the potential role of parents' financial conditions on the lending growth of the foreign affiliates in developing countries. In particular, we interact parent size, equity, liquidity, and deposit funding structure with our foreign ownership dummy. The idea behind these estimations is to determine whether loan growth by foreign affiliates of more financially sound parents was different than that for other foreign affiliates.

\section{Results}

Table 2 column (1) shows the results from estimating equation (1) for the growth of total gross loans over 2005-2009. As other studies have uncovered (e.g., De Haas et al., 2011; Claessens and van Horen, 2013; Cull and Martinez Peria, 2013; De Haas and van Lelyveld, 2013), we find that at the height of the global financial crisis, in 2009, foreign banks curtailed credit growth more than domestic banks (column 1). Thus, foreign ownership affects credit behavior, even after controlling for bank characteristics and macroeconomic conditions. At the same time, we find that a higher deposit base (and thus less reliance on wholesale funding) and stronger capitalization have a positive effect on credit growth.

A potentially important limitation of the estimation in column (1) is that it considers all domestic banks as one category, while it is possible that private and government-owned banks may behave differently during a crisis. In particular, government-owned banks may expand credit more that private banks in times of crisis if risk aversion is more pro-cyclical in private banks and the government is 
more risk-neutral through the cycle. Hence, in column (2) of Table 2, we present results allowing for a different behavior of government-owned banks, by including a separate dummy for this category of banks. When comparing the behavior of foreign banks to that of domestic private banks, we continue to find that foreign banks curtailed credit more in 2009. We also find evidence that government-owned banks behaved counter cyclically during the crisis, as they expanded credit more than private domestic banks.

Table 3 explores differences in banks' behavior across regions. Much has been discussed about the foreign bank lending contraction in ECA, but we find that our results are not driven by the behavior of foreign banks in ECA. In fact, we find that foreign banks in EAP and the European countries in ECA did not behave differently than foreign banks in LAC, as interactions between Foreign and regional dummies are not significant (column 1). ${ }^{10)}$ At the same time, foreign banks in the former soviet republics (FSU) seem to have expanded credit (relative to domestic banks) by more than foreign banks in the other regions. Consistent with De Haas et al. (2012), we also find evidence that the Vienna Initiative worked; foreign banks in Vienna initiative countries expanded credit more than other foreign banks. When controlling for government bank ownership, we still find the same results (column 2). The behavior of foreign banks vis-a-vis private domestic banks is similar in all regions (now also including FSU), with the exception of Vienna Initiative countries. We also find that government-owned banks behaved in a similar counter-cyclical role in all regions in 2009.

To assess whether there is heterogeneity in the reaction to the crisis among foreign banks depending on their balance sheet characteristics, we include interactions of the foreign ownership dummy with our measures of bank size, capitalization, liquidity, and deposit funding structure (Table 4). We find, as Claessens and Van Horen (2013) and De Haas and van Lelyveld (2013), that foreign banks with a higher deposit funding base exhibited a faster credit growth rate than other foreign banks in 2009 (column 1). However funding structure does not

10) To avoid multicollinearity problems we introduced interaction terms for foreign ownership and region where the bank operates for all regions in the sample but one, LAC. Thus, the negative sign for foreign bank ownership in 2009 reflects the behavior of LAC banks. 


\section{Table 2: Baseline Regressions}

\begin{tabular}{|c|c|c|}
\hline \multicolumn{3}{|c|}{ Dependent variable: Real Annual Growth in Total Gross Loans } \\
\hline & (1) & (2) \\
\hline Foreign $\times$ Crisis 2008 & $\begin{array}{c}0.069 \\
(3.34)^{* * *}\end{array}$ & $\begin{array}{l}0.101 \\
(4.67)^{* * *}\end{array}$ \\
\hline Foreign $\times$ Crisis 2009 & $\begin{array}{l}-0.079 \\
(3.99)^{* * *}\end{array}$ & $\begin{array}{l}-0.049 \\
(2.30)^{* *}\end{array}$ \\
\hline Government $\times$ Crisis 2008 & & $\begin{array}{c}0.132 \\
(5.34)^{* * *}\end{array}$ \\
\hline Government x Crisis 2009 & & $\begin{array}{l}0.118 \\
(4.92)^{* * *}\end{array}$ \\
\hline Deposit Funding Ratio(07_08) x Crisis 2008 & $\begin{array}{c}0.081 \\
(1.77)^{*}\end{array}$ & $\begin{array}{c}0.104 \\
(2.31)^{* *}\end{array}$ \\
\hline Deposit Funding Ratio(07_08) x Crisis 2009 & $\begin{array}{c}0.136 \\
(2.98)^{* * *}\end{array}$ & $\begin{array}{c}0.159 \\
(3.51)^{* * *}\end{array}$ \\
\hline Size $_{\left(07 \_08\right)} \times$ Crisis 2008 & $\begin{array}{c}0.005 \\
(0.76)\end{array}$ & $\begin{array}{r}-0.003 \\
(0.40)\end{array}$ \\
\hline Size $_{\left(07 \_08\right)} \times$ Crisis 2009 & $\begin{array}{c}0.008 \\
(1.18)\end{array}$ & $\begin{array}{c}0.002 \\
(0.21)\end{array}$ \\
\hline Equity Ratio(07_08) x Crisis 2008 & $\begin{array}{c}0.374 \\
(3.03)^{* * *}\end{array}$ & $\begin{array}{l}0.343 \\
(2.78)^{* * *}\end{array}$ \\
\hline Equity Ratio(07_08) x Crisis 2009 & $\begin{array}{c}0.336 \\
(2.51)^{* *}\end{array}$ & $\begin{array}{c}0.308 \\
(2.25)^{* *}\end{array}$ \\
\hline Liquidity Ratio(07_08) x Crisis 2008 & $\begin{array}{c}0.342 \\
(4.17)^{* * *}\end{array}$ & $\begin{array}{c}0.319 \\
(3.90)^{* * *}\end{array}$ \\
\hline Liquidity Ratio(07_08) $\times$ Crisis 2009 & $\begin{array}{c}0.141 \\
(1.64)\end{array}$ & $\begin{array}{c}0.125 \\
(1.46)\end{array}$ \\
\hline Bank FE & Y & Y \\
\hline Country $\times$ Year FE & Y & Y \\
\hline $\mathrm{R}$-squared & 0.58 & 0.59 \\
\hline \# observations & 5,167 & 5,167 \\
\hline
\end{tabular}

Notes: This table presents the results of baseline regressions with bank-level panel data from 2005 to 2009. The dependent variable is the log difference of gross loans (in millions of USD adjusted with US CPI) of bank $i$ in country $j$ at time $t$. Foreign is a dummy variable which equals 1 if the bank is foreign owned. Government is a dummy variable which equals 1 if the bank is government owned. Deposit Funding Ratio is the ratio of total customer deposits to total liabilities, Size is the log of total assets (in millions of USD adjusted with US CPI), Equity Ratio is the ratio of equity to total assets, and Liquidity Ratio is the ratio of liquid assets to total assets. These four bank-characteristics variables are average of 2007 and 2008 values. Crisis 2008 (2009) is a dummy which equals 1 if the year is 2008 (2009). Robust standard errors of coefficient estimates are reported in parentheses and $* * *$, ** and $*$ indicate the $1 \%, 5 \%$, and $10 \%$ level of significance, respectively. 


\section{$15 \quad$ BOK Working Paper No.2014-07 (2014.04)}

Table 3: Regressions with Regional Dummies (Benchmark region: LAC)

\begin{tabular}{|c|c|c|}
\hline \multicolumn{3}{|c|}{ Dependent variable: Real Annual Growth in Total Gross Loans } \\
\hline & (1) & (2) \\
\hline Foreign $\times$ Crisis 2008 & $\begin{array}{c}0.046 \\
(1.43)\end{array}$ & $\begin{array}{c}0.083 \\
(2.49)^{* *}\end{array}$ \\
\hline Foreign $\times$ Crisis 2009 & $\begin{array}{l}-0.118 \\
(3.45)^{* * *}\end{array}$ & $\begin{array}{l}-0.091 \\
(2.51)^{* *}\end{array}$ \\
\hline Government x Crisis 2008 & & $\begin{array}{c}0.176 \\
(5.17)^{* * *}\end{array}$ \\
\hline Government x Crisis 2009 & & $\begin{array}{c}0.121 \\
(3.30)^{* * *}\end{array}$ \\
\hline Deposit Funding Ratio(07_08) $\times$ Crisis 2008 & $\begin{array}{r}0.080 \\
(1.75)^{*}\end{array}$ & $\begin{array}{c}0.098 \\
(2.15)^{* *}\end{array}$ \\
\hline Deposit Funding Ratio(07_08) $\times$ Crisis 2009 & $\begin{array}{c}0.138 \\
(3.00)^{* * *}\end{array}$ & $\begin{array}{c}0.162 \\
(3.47)^{* * *}\end{array}$ \\
\hline Size $_{\left(07 \_08\right)} \times$ Crisis 2008 & $\begin{array}{c}0.006 \\
(0.95)\end{array}$ & $\begin{array}{r}-0.002 \\
(0.31)\end{array}$ \\
\hline Size(07_08) x Crisis 2009 & $\begin{array}{c}0.009 \\
(1.25)\end{array}$ & $\begin{array}{l}0.002 \\
(0.26)\end{array}$ \\
\hline Equity Ratio(07_08) x Crisis 2008 & $\begin{array}{c}0.383 \\
(3.11)^{* * *}\end{array}$ & $\begin{array}{l}0.353 \\
(2.84)^{* * *}\end{array}$ \\
\hline Equity Ratio(07_08) x Crisis 2009 & $\begin{array}{c}0.347 \\
(2.58)^{* * *}\end{array}$ & $\begin{array}{l}0.317 \\
(2.30)^{* *}\end{array}$ \\
\hline Liquidity Ratio(07_08) $\times$ Crisis 2008 & $\begin{array}{c}0.333 \\
(4.05)^{* * *}\end{array}$ & $\begin{array}{l}0.312 \\
(3.78)^{* * *}\end{array}$ \\
\hline Liquidity Ratio(07_08) X Crisis 2009 & $\begin{array}{c}0.147 \\
(1.71)^{*}\end{array}$ & $\begin{array}{c}0.129 \\
(1.49)\end{array}$ \\
\hline Foreign $\times$ Crisis $2008 \times$ ECA_VI & $\begin{array}{c}0.011 \\
(0.16)\end{array}$ & $\begin{array}{l}0.036 \\
(0.54)\end{array}$ \\
\hline Foreign $\times$ Crisis $2008 \times$ ECA_FSU & $\begin{array}{c}0.143 \\
(1.81)^{*}\end{array}$ & $\begin{array}{c}0.140 \\
(1.71)^{*}\end{array}$ \\
\hline Foreign $\times$ Crisis $2008 \times$ ECA_Europe & $\begin{array}{r}-0.007 \\
(0.13)\end{array}$ & $\begin{array}{c}-0.033 \\
(0.60)\end{array}$ \\
\hline Foreign $\times$ Crisis $2008 \times$ EAP & $\begin{array}{l}0.013 \\
(0.25)\end{array}$ & $\begin{array}{c}-0.003 \\
(0.06)\end{array}$ \\
\hline Foreign $\times$ Crisis $2009 \times$ ECA_VI & $\begin{array}{c}0.093 \\
(1.55)\end{array}$ & $\begin{array}{c}0.115 \\
(1.89)^{*}\end{array}$ \\
\hline Foreign $\times$ Crisis $2009 \times$ ECA_FSU & $\begin{array}{c}0.119 \\
(1.67)^{*}\end{array}$ & $\begin{array}{r}0.115 \\
(1.49)\end{array}$ \\
\hline Foreign $\times$ Crisis $2009 \times$ ECA_Europe & $\begin{array}{l}0.041 \\
(0.80)\end{array}$ & $\begin{array}{l}0.050 \\
(0.91)\end{array}$ \\
\hline Foreign $\times$ Crisis $2009 \times$ EAP & $\begin{array}{l}0.030 \\
(0.54)\end{array}$ & $\begin{array}{l}0.037 \\
(0.65)\end{array}$ \\
\hline Government $\times$ Crisis 2008 x ECA_VI & & $\begin{array}{l}0.030 \\
(0.23)\end{array}$ \\
\hline
\end{tabular}




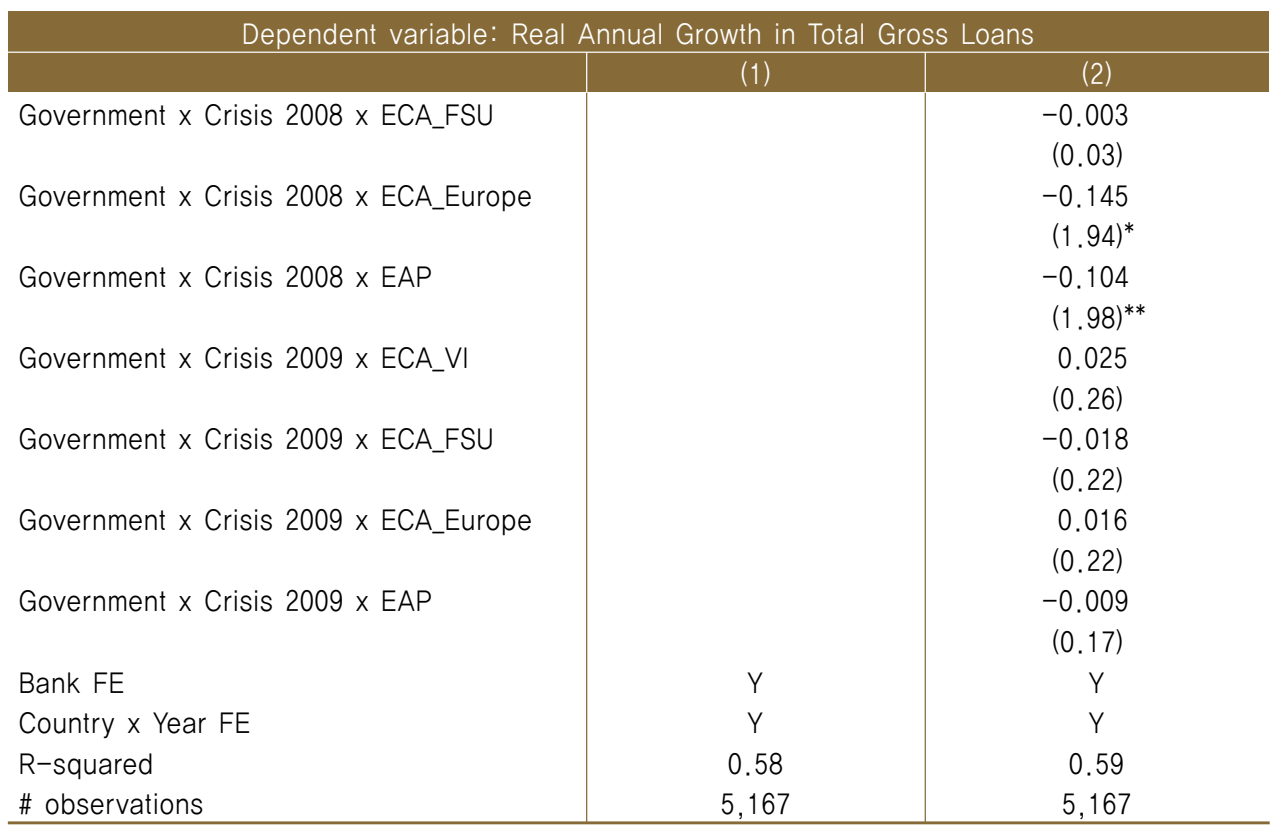

Notes: This table presents the results of regressions with interaction terms of Foreign, Crisis and sub-region dummies. $E C A_{-} V I$ indicates a dummy variable which equals 1 if the country belongs to Vienna Initiative countries, ECA_FSU indicates a dummy variable which equals 1 if the country is in the Former Soviet Union group, and ECA_Europe indicates the rest of European countries in the sample. EAP indicates a dummy variable which equals 1 if the country is in East Asia. Robust standard errors of coefficient estimates are reported in parentheses and ${ }^{* *},{ }^{* *}$ and $*$ correspond to the $1 \%, 5 \%$, and $10 \%$ level of significance, respectively.

completely explain the behavior of foreign banks as the foreign bank dummy continues to be negative in 2009.11) We also find that large foreign banks experienced a lower credit growth rate in 2008 than other foreign banks, as large banks from developed countries tended to be more exposed to US subprime assets and, thus, where amongst the most affected at the onset of the global financial crisis (column 2). Other bank characteristics, such as capital or liquidity, did not have a differential effect for foreign banks (columns 3 and 4).

In Table 5, we analyze the extent to which the relative importance of the foreign affiliates within a foreign parent group had an impact on the behavior of foreign

11) Ideally, we would also like to explore if foreign bank behavior was affected by whether or not foreign banks relied on cross-border lending or foreign currency funding, but unfortunately Bankscope does not include data on funding by origin (i.e. domestic or foreign) or currency denomination. 
banks. To do so we explore if larger foreign bank operations in terms of total group assets (column 1) or operations that generate a larger share of group profits (column 2) curtailed credit by less relative to other banks, as the parent may reduce activity first in non-core operations. It is important to notice that some of the foreign banks in our sample do not have a financial sector parent, but a real sector parent, such as a department store or a car company. Since there is no information on the financial condition of non-financial companies in Bankscope, we lose about 7 percent of the observations in our sample in this regression. ${ }^{12)}$ We find no effect of the relative importance of the foreign bank operation on its credit behavior in 2009. We find, however, that in 2008 , when foreign banks were more credit expansive than domestic banks, foreign operations accounting for a larger share of parent group assets were growing credit by less than other foreign banks (column 1).

In Tables 6 and 7, we explore whether parent characteristics can help explain foreign bank behavior. In particular, Table 6 examines the effects of the geographic reach (regional versus global) and the origin of the parent. In column (1), we define foreign regional banks as those that operate only in the same region as the one where the headquarters of the parent is located.13) Potentially, regional banks may be more willing to maintain the credit growth of their affiliates than global banks as the former are closer to the countries in which they operate and may be more reliant on them due to lower diversification. However, we find that regional banks did not behave differently than global foreign banks that operate in multiple regions (column 1). To assess the impact of the country of origin of the parent, we split the sample between US banks, European banks, and other foreign banks (comprising mostly Canadian, Japanese, and some Middle Eastern banks). We find that, in contrast to other foreign banks, US banks operating overseas did not appear to have curtailed credit growth in 2009 (column 2), perhaps because by 2009 US banks had received a lot of financial support from regulators and the US economy was slowly coming out of the crisis. ${ }^{14)}$

12) We lose an additional 10 percent of the sample for which information on parent profits is missing.

13) Some regional banks have representation offices or small operations in off-shore financial centers outside from the region where the parent is located but, given that these operations are small, we continue to classify these banks as regional.

14) The sum of the Foreign $\times 2009$ and US Foreign $\times 2009$ coefficient is approximately zero. 
Table 4: Regressions with Triple Interactions with Bank Characteristics

\begin{tabular}{|c|c|c|c|c|}
\hline \multicolumn{5}{|c|}{ Dependent variable: Real Annual Growth in Total Gross Loans } \\
\hline \multirow{2}{*}{ Bank Characteristics } & $\begin{array}{l}\text { Deposit } \\
\text { Funding } \\
\end{array}$ & Size & Equity & Liquidity \\
\hline & (1) & (2) & (3) & (4) \\
\hline \multirow[t]{2}{*}{ Foreign $\times$ Crisis 2008} & 0.150 & 0.264 & 0.048 & 0.135 \\
\hline & $(2.48)^{* *}$ & $(3.52)^{* * *}$ & $(1.31)$ & $(3.61)^{* * *}$ \\
\hline \multirow[t]{2}{*}{ Foreign $\times$ Crisis 2009} & -0.152 & -0.065 & -0.006 & -0.013 \\
\hline & $(2.38)^{* *}$ & $(0.86)$ & $(0.16)$ & $(0.35)$ \\
\hline \multirow[t]{2}{*}{ Government $x$ Crisis 2008} & 0.134 & 0.121 & 0.130 & 0.132 \\
\hline & $(5.40)^{* * *}$ & $(4.86)^{* * *}$ & $(5.28)^{* * *}$ & $(5.32)^{* * *}$ \\
\hline \multirow[t]{2}{*}{ Government $\times$ Crisis 2009} & 0.114 & 0.119 & 0.120 & 0.118 \\
\hline & $(4.71)^{* * *}$ & $(4.96)^{* * *}$ & $(5.07)^{* * *}$ & $(4.92)^{* * *}$ \\
\hline \multirow[t]{2}{*}{ Foreign $\times$ Crisis $2008 \times$ Bank Characteristics } & -0.075 & -0.024 & 0.334 & -0.129 \\
\hline & $(0.95)$ & $(2.46)^{* *}$ & $(1.48)$ & $(0.91)$ \\
\hline \multirow[t]{2}{*}{ Foreign $\times$ Crisis $2009 \times$ Bank Characteristics } & 0.158 & 0.002 & -0.269 & -0.140 \\
\hline & $(1.90)^{*}$ & $(0.25)$ & $(1.21)$ & $(0.97)$ \\
\hline \multirow[t]{2}{*}{ Deposit Funding Ratio(07_08) $\times$ Crisis 2008} & 0.140 & 0.099 & 0.096 & 0.110 \\
\hline & $(2.53)^{* *}$ & $(2.21)^{* *}$ & $(2.16)^{* *}$ & $(2.47)^{* *}$ \\
\hline \multirow[t]{2}{*}{ Deposit Funding Ratio(07_08) x Crisis 2009} & 0.089 & 0.159 & 0.164 & 0.166 \\
\hline & $(1.63)$ & $(3.52)^{* * *}$ & $(3.67)^{* * *}$ & $(3.67)^{* * *}$ \\
\hline \multirow[t]{2}{*}{ Size(07_08) $\times$ Crisis 2008} & -0.002 & 0.006 & -0.001 & -0.003 \\
\hline & $(0.33)$ & $(0.92)$ & $(0.23)$ & $(0.47)$ \\
\hline \multirow[t]{2}{*}{ Size $_{\left(07 \_08\right)} \times$ Crisis 2009} & 0.001 & 0.001 & 0.001 & 0.001 \\
\hline & $(0.12)$ & $(0.08)$ & $(0.13)$ & $(0.13)$ \\
\hline \multirow[t]{2}{*}{ Equity Ratio(07_08) $\times$ Crisis 2008} & 0.351 & 0.318 & 0.180 & 0.352 \\
\hline & $(2.86)^{* * *}$ & $(2.62)^{* * *}$ & $(1.61)$ & $(2.87)^{* * *}$ \\
\hline \multirow[t]{2}{*}{ Equity Ratio(07_08) x Crisis 2009} & 0.291 & 0.312 & 0.438 & 0.315 \\
\hline & $(2.18)^{* *}$ & $(2.27)^{* *}$ & $(2.41)^{* *}$ & $(2.30)^{* *}$ \\
\hline \multirow[t]{2}{*}{ Liquidity Ratio(07_08) $\times$ Crisis 2008} & 0.327 & 0.298 & 0.297 & 0.385 \\
\hline & $(3.99)^{* * *}$ & $(3.66)^{* * *}$ & $(3.65)^{* * *}$ & $(3.89)^{* * *}$ \\
\hline \multirow[t]{2}{*}{ Liquidity Ratio(07_08) $\times$ Crisis 2009} & 0.105 & 0.128 & 0.142 & 0.196 \\
\hline & $(1.22)$ & $(1.51)$ & $(1.66)^{*}$ & $(2.01)^{* *}$ \\
\hline Bank FE & Y & Y & Y & Y \\
\hline Country $x$ Year FE & Y & Y & Y & Y \\
\hline R-squared & 0.59 & 0.59 & 0.59 & 0.59 \\
\hline \# observations & 5,167 & 5,167 & 5,167 & 5,167 \\
\hline
\end{tabular}

Notes: This table reports the results of regressions with interaction of Foreign, Crisis, and each bank characteristics (Deposit funding ratio, Size, Equity ratio, and Liquidity ratio). Robust standard errors of coefficient estimates are reported in parentheses and $* * *, * *$ and * indicate the $1 \%, 5 \%$, and $10 \%$ level of significance, respectively. 


\section{$19 \quad$ BOK Working Paper No.2014-07 (2014.04)}

\section{Table 5: Regressions with Measures of the Importance of Affiliates}

\begin{tabular}{|c|c|c|}
\hline \multicolumn{3}{|c|}{$\begin{array}{l}\text { Dependent variable: Real Annual Growth in Total Gross Loans } \\
\text { Foreign affiliate to parent }\end{array}$} \\
\hline \multirow[t]{2}{*}{ Parent Characteristics } & $\begin{array}{c}\text { Foreign } \\
\text { affiliate-parent } \\
\text { size ratio } \\
\end{array}$ & $\begin{array}{c}\text { Foreign } \\
\text { affiliate-parent } \\
\text { profitability ratio } \\
\end{array}$ \\
\hline & (1) & (2) \\
\hline Foreign $\times$ Crisis 2008 & $\begin{array}{l}0.230 \\
(3.45)^{* * *}\end{array}$ & $\begin{array}{l}0.119 \\
(4.89)^{* * *}\end{array}$ \\
\hline Foreign $\times$ Crisis 2009 & $\begin{array}{l}-0.112 \\
(1.70)^{*}\end{array}$ & $\begin{array}{l}-0.045 \\
(1.86)^{*}\end{array}$ \\
\hline Government x Crisis 2008 & $\begin{array}{l}0.119 \\
(4.79)^{* * *}\end{array}$ & $\begin{array}{l}0.130 \\
(5.12)^{* * *}\end{array}$ \\
\hline Government x Crisis 2009 & $\begin{array}{l}0.114 \\
(4.74)^{* * *}\end{array}$ & $\begin{array}{l}0.116 \\
(4.73)^{* * *}\end{array}$ \\
\hline Foreign $\times$ Crisis 2008 x Foreign Affiliate Importance(07_08) & $\begin{array}{l}-0.229 \\
(2.44)^{* *}\end{array}$ & $\begin{array}{l}-0.002 \\
(1.30)\end{array}$ \\
\hline Foreign $\times$ Crisis 2009 x Foreign Affiliate Importance(07_08) & $\begin{array}{l}0.094 \\
(1.01)\end{array}$ & $\begin{array}{l}-0.002 \\
(1.06)\end{array}$ \\
\hline Deposit Funding Ratio(07_08) x Crisis 2008 & $\begin{array}{l}0.091 \\
(1.92)^{*}\end{array}$ & $\begin{array}{l}0.091 \\
(1.90)^{*}\end{array}$ \\
\hline Deposit Funding Ratio(07_08) x Crisis 2009 & $\begin{array}{l}0.135 \\
(2.87)^{* * *}\end{array}$ & $\begin{array}{l}0.130 \\
(2.66)^{* * *}\end{array}$ \\
\hline Size $_{\left(07 \_08\right)} \times$ Crisis 2008 & $\begin{array}{l}0.005 \\
(0.72)\end{array}$ & $\begin{array}{l}-0.002 \\
(0.26)\end{array}$ \\
\hline Size $_{\left(07 \_08\right)} \times$ Crisis 2009 & $\begin{array}{l}0.003 \\
(0.34)\end{array}$ & $\begin{array}{l}0.004 \\
(0.52)\end{array}$ \\
\hline Equity Ratio(07_08) x Crisis 2008 & $\begin{array}{l}0.343 \\
(3.06)^{* * *}\end{array}$ & $\begin{array}{l}0.337 \\
(2.95)^{* * *}\end{array}$ \\
\hline Equity Ratio(07_08) x Crisis 2009 & $\begin{array}{l}0.328 \\
(2.28)^{* *}\end{array}$ & $\begin{array}{l}0.312 \\
(2.04)^{* *}\end{array}$ \\
\hline Liquidity Ratio(07_08) x Crisis 2008 & $\begin{array}{l}0.341 \\
(4.12)^{* * *}\end{array}$ & $\begin{array}{l}0.374 \\
(4.28)^{* * *}\end{array}$ \\
\hline Liquidity Ratio(07_08) x Crisis 2009 & $\begin{array}{l}0.148 \\
(1.73)^{*}\end{array}$ & $\begin{array}{l}0.143 \\
(1.54)\end{array}$ \\
\hline Bank FE & Y & Y \\
\hline Country $x$ Year FE & Y & Y \\
\hline R-squared & 0.59 & 0.62 \\
\hline \# observations & 4,767 & 4,387 \\
\hline
\end{tabular}

Notes: This table presents the results of regressions with measures of the importance of foreign affiliate. Columns (1) and (2) include triple interactions with foreign affiliate' importance to their parent. The measures for the importance used in column (1) is the ratio of size of foreign affiliates to size of parent banks, and the measure used in column (2) is the ratio of profitability (ROAA) of foreign affiliates to profitability of parent. All measures are based on 2007-2008 average values. Foreign banks without parent information are not included in the samples in columns (1) and (2). Robust standard errors of coefficient estimates are reported in parentheses and $* * *, * *$ and * indicate the $1 \%, 5 \%$, and $10 \%$ level of significance, respectively. 
In Table 7, we explore whether the financial characteristics of the parent help explain the behavior of foreign bank affiliates in host jurisdictions. ${ }^{15)}$ The results highlight the importance of the equity channel. We find that foreign banks whose parent had stronger capital ratios curtailed credit less than other foreign banks (columns 3 and 5). Moreover, the introduction of parent characteristics (especially parent capitalization) seems to fully explain the differential behavior of foreign banks in 2009, since the foreign ownership dummy is no longer significant by itself once we include the interaction term (column 5). As parents become capital constrained, they seem to retrench credit in host countries with a view to bolster capital at the consolidated level. On the other hand, the funding model of the parent doesn't seem to explain the foreign bank credit retrenchment in 2009.

Finally, in Table 8, we explore the relative importance of the funding structure of the foreign affiliate and the capitalization of the parent in explaining the behavior of foreign banks in developing countries during the crisis. To control for differences in sample size we re-run the regression in which we interact foreign ownership with affiliate characteristics with the same sample we used to explore the effect of financial characteristics of the parent (column 2). When we do so, we no longer find that lower reliance by the affiliate on wholesale funding has a positive effect on foreign bank lending in 2009. Thus, our previous results seem to have been driven by the behavior of foreign banks whose parents are non-financial institutions. For these banks, reliance on wholesale funding is likely based on money market funding, while for the foreign banks whose parents are banks, wholesale funding is likely to have been primarily parent funding. When we interact both the affiliate characteristic and parent characteristic with foreign ownership, we still find that the capital of the parent explains the differential behavior of foreign banks in 2009 (column 3).

15) The reason why in this table there are no double interactions with parent characteristics is that the triple interaction already account for the parent characteristics since the parent characteristics are only available for foreign banks. i.e. Crisis $\times$ Parent characteristics are the same as Foreign $\times$ Crisis $\times$ Parent characteristics, since only foreign banks have parent characteristics, and Foreign $\times$ Parent characteristics is the same as Parent characteristics, which are controlled for by bank fixed effects. 


\section{Table 6: Regressions with Parent Characteristics}

\begin{tabular}{|c|c|c|}
\hline \multicolumn{3}{|c|}{ Dependent variable: Real Annual Growth in Total Gross Loans } \\
\hline \multirow{2}{*}{ Parent Characteristics } & Foreign Global vs. Regional & Origin of parent \\
\hline & (1) & (2) \\
\hline Foreign $\times$ Crisis 2008 & $\begin{array}{l}0.111 \\
(3.77)^{* * *}\end{array}$ & $\begin{array}{l}0.100 \\
(2.84)^{* * *}\end{array}$ \\
\hline Foreign $\times$ Crisis 2009 & $\begin{array}{l}-0.058 \\
(2.06)^{* *}\end{array}$ & $\begin{array}{l}-0.086 \\
(2.52)^{* *}\end{array}$ \\
\hline Foreign Regional $\times$ Crisis 2008 & $\begin{array}{l}-0.014 \\
(0.47)\end{array}$ & \\
\hline Foreign Regional x Crisis 2009 & $\begin{array}{l}0.014 \\
(0.50)\end{array}$ & \\
\hline Foreign US $\times$ Crisis 2008 & & $\begin{array}{l}0.003 \\
(0.05)\end{array}$ \\
\hline Foreign US $\times$ Crisis 2009 & & $\begin{array}{l}0.095 \\
(1.76)^{*}\end{array}$ \\
\hline Foreign EU $\times$ Crisis 2008 & & $\begin{array}{l}0.002 \\
(0.04)\end{array}$ \\
\hline Foreign EU x Crisis 2009 & & $\begin{array}{l}0.045 \\
(1.15)\end{array}$ \\
\hline Government $\times$ Crisis 2008 & $\begin{array}{l}0.133 \\
(5.35)^{* * *}\end{array}$ & $\begin{array}{l}0.132 \\
(5.35)^{* * *}\end{array}$ \\
\hline Government x Crisis 2009 & $\begin{array}{l}0.118 \\
(4.91)^{* * *}\end{array}$ & $\begin{array}{l}0.120 \\
(5.00)^{* * *}\end{array}$ \\
\hline Deposit Funding Ratio(07_08) x Crisis 2008 & $\begin{array}{l}0.104 \\
(2.32)^{* *}\end{array}$ & $\begin{array}{l}0.104 \\
(2.24)^{* *}\end{array}$ \\
\hline Deposit Funding Ratio(07_08) x Crisis 2009 & $\begin{array}{l}0.159 \\
(3.51)^{* * *}\end{array}$ & $\begin{array}{l}0.165 \\
(3.62)^{* * *}\end{array}$ \\
\hline Size(07_08) x Crisis 2008 & $\begin{array}{l}-0.003 \\
(0.45)\end{array}$ & $\begin{array}{l}-0.003 \\
(0.41)\end{array}$ \\
\hline Size(07_08) $\times$ Crisis 2009 & $\begin{array}{l}0.002 \\
(0.25)\end{array}$ & $\begin{array}{l}0.000 \\
(0.05)\end{array}$ \\
\hline Equity Ratio(07_08) x Crisis 2008 & $\begin{array}{l}0.345 \\
(2.81)^{* * *}\end{array}$ & $\begin{array}{l}0.344 \\
(2.76)^{* * *}\end{array}$ \\
\hline Equity Ratio(07_08) x Crisis 2009 & $\begin{array}{l}0.305 \\
(2.22)^{* *}\end{array}$ & $\begin{array}{l}0.317 \\
(2.29)^{* *}\end{array}$ \\
\hline Liquidity Ratio(07_08) $\times$ Crisis 2008 & $\begin{array}{l}0.317 \\
(3.86)^{* * *}\end{array}$ & $\begin{array}{l}0.318 \\
(3.87)^{* * *}\end{array}$ \\
\hline Liquidity Ratio(07_08) x Crisis 2009 & $\begin{array}{l}0.128 \\
(1.50)\end{array}$ & $\begin{array}{l}0.125 \\
(1.46)\end{array}$ \\
\hline Bank FE & Y & Y \\
\hline Country $x$ Year FE & Y & Y \\
\hline $\mathrm{R}$-squared & 0.59 & 0.59 \\
\hline \# observations & 5,167 & 5,167 \\
\hline
\end{tabular}

Notes: This table reports the results of regressions with interaction of crisis and dummy variables representing parent characteristics. Foreign Regional is a dummy variable which equals 1 if the bank is foreign owned and its parent operate within a specific region, which is not classified as Foreign Global Groups (FGG) listed in Table C. Foreign US is a dummy variable which equals 1 if the bank is foreign owned and its parent is from the US, and Foreign EU is a dummy variable which equals 1 if the bank is foreign owned and its parent is based in Europe. Robust standard errors of coefficient estimates are reported in parentheses and $* * *, * *$ and * indicate the $1 \%, 5 \%$, and $10 \%$ level of significance, respectively. 


\section{Table 7: Regressions with Parent Financial Characteristics}

\begin{tabular}{|c|c|c|c|c|c|}
\hline \multicolumn{6}{|c|}{ Dependent variable: Real Annual Growth in Total Gross Loans } \\
\hline & $(1)$ & $(2)$ & (3) & $(4)$ & $(5)$ \\
\hline Foreign $\times$ Crisis 2008 & $\begin{array}{l}0.086 \\
(2.06)^{* *}\end{array}$ & $\begin{array}{l}0.090 \\
(1.44)\end{array}$ & $\begin{array}{l}0.117 \\
(4.11)^{* * *}\end{array}$ & $\begin{array}{l}0.115 \\
(3.13)^{* * *}\end{array}$ & $\begin{array}{l}0.072 \\
(0.84)\end{array}$ \\
\hline Foreign $\times$ Crisis 2009 & $\begin{array}{l}-0.043 \\
(0.97)\end{array}$ & $\begin{array}{l}-0.066 \\
(0.97)\end{array}$ & $\begin{array}{l}-0.102 \\
(3.44)^{* * *}\end{array}$ & $\begin{array}{l}-0.058 \\
(1.60)\end{array}$ & $\begin{array}{l}-0.120 \\
(1.19)\end{array}$ \\
\hline $\begin{array}{l}\text { Foreign } \times \text { Crisis } 2008 \times \text { Parent Deposit } \\
\text { Funding }(07-08)\end{array}$ & $\begin{array}{l}0.040 \\
(0.52)\end{array}$ & & & & $\begin{array}{l}0.073 \\
(0.72)\end{array}$ \\
\hline $\begin{array}{l}\text { Foreign } \times \text { Crisis } 2009 \times \text { Parent Deposit } \\
\text { Funding }(07-08)\end{array}$ & $\begin{array}{l}-0.041 \\
(0.53)\end{array}$ & & & & $\begin{array}{l}-0.130 \\
(1.37)\end{array}$ \\
\hline Foreign $\times$ Crisis $2008 \times$ Parent Size (07-08) & & $\begin{array}{l}0.001 \\
(0.23)\end{array}$ & & & $\begin{array}{l}0.003 \\
(0.48)\end{array}$ \\
\hline Foreign $\times$ Crisis $2009 \times$ Parent Size (07-08) & & $\begin{array}{l}0.001 \\
(0.12)\end{array}$ & & & $\begin{array}{l}0.005 \\
(0.70)\end{array}$ \\
\hline Foreign $\times$ Crisis $2008 \times$ Parent Equity (07-08) & & & $\begin{array}{l}-0.109 \\
(0.51)\end{array}$ & & $\begin{array}{l}-0.275 \\
(0.43)\end{array}$ \\
\hline Foreign $\times$ Crisis $2009 \times$ Parent Equity (07-08) & & & $\begin{array}{l}0.665 \\
(2.78)^{* * *}\end{array}$ & & $\begin{array}{l}1.083 \\
(1.73)^{*}\end{array}$ \\
\hline Foreign $\times$ Crisis $2008 \times$ Parent Liquidity (07-08) & & & & $\begin{array}{l}-0.062 \\
(0.44)\end{array}$ & $\begin{array}{l}-0.100 \\
(0.61)\end{array}$ \\
\hline Foreign $\times$ Crisis $2009 \times$ Parent Liquidity (07-08) & & & & $\begin{array}{l}-0.000 \\
(0.00)\end{array}$ & $\begin{array}{l}-0.036 \\
(0.23)\end{array}$ \\
\hline Government x Crisis 2008 & $\begin{array}{l}0.129 \\
(5.20)^{* * *}\end{array}$ & $\begin{array}{l}0.129 \\
(5.14)^{* * *}\end{array}$ & $\begin{array}{l}0.131 \\
(5.22)^{* * *}\end{array}$ & $\begin{array}{l}0.127 \\
(5.09)^{* * *}\end{array}$ & $\begin{array}{l}0.131 \\
(5.24)^{* * *}\end{array}$ \\
\hline Government x Crisis 2009 & $\begin{array}{l}0.111 \\
(4.56)^{* * *}\end{array}$ & $\begin{array}{l}0.112 \\
(4.61)^{* * *}\end{array}$ & $\begin{array}{l}0.113 \\
(4.65)^{* * *}\end{array}$ & $\begin{array}{l}0.114 \\
(4.68)^{* * *}\end{array}$ & $\begin{array}{l}0.115 \\
(4.70)^{* * *}\end{array}$ \\
\hline Deposit Funding Ratio(07-08) x Crisis 2008 & $\begin{array}{l}0.094 \\
(1.96)^{*}\end{array}$ & $\begin{array}{l}0.091 \\
(1.96)^{*}\end{array}$ & $\begin{array}{l}0.091 \\
(1.95)^{*}\end{array}$ & $\begin{array}{l}0.088 \\
(1.88)^{*}\end{array}$ & $\begin{array}{l}0.092 \\
(1.90)^{*}\end{array}$ \\
\hline Deposit Funding Ratio(07-08) x Crisis 2009 & $\begin{array}{l}0.145 \\
(3.06)^{* * *}\end{array}$ & $\begin{array}{l}0.138 \\
(2.95)^{* * *}\end{array}$ & $\begin{array}{l}0.130 \\
(2.77)^{* * *}\end{array}$ & $\begin{array}{l}0.142 \\
(3.02)^{* * *}\end{array}$ & $\begin{array}{l}0.147 \\
(3.08)^{* * *}\end{array}$ \\
\hline $\operatorname{Size}_{(07-08)} \times$ Crisis 2008 & $\begin{array}{l}-0.002 \\
(0.27)\end{array}$ & $\begin{array}{l}-0.002 \\
(0.24)\end{array}$ & $\begin{array}{l}-0.003 \\
(0.42)\end{array}$ & $\begin{array}{l}-0.001 \\
(0.18)\end{array}$ & $\begin{array}{l}-0.003 \\
(0.47)\end{array}$ \\
\hline Size $_{(07-08)} \times$ Crisis 2009 & $\begin{array}{l}0.006 \\
(0.80)\end{array}$ & $\begin{array}{l}0.004 \\
(0.60)\end{array}$ & $\begin{array}{l}0.004 \\
(0.55)\end{array}$ & $\begin{array}{l}0.004 \\
(0.49)\end{array}$ & $\begin{array}{l}0.003 \\
(0.45)\end{array}$ \\
\hline Equity Ratio(07-08) x Crisis 2008 & $\begin{array}{l}0.329 \\
(2.90)^{* * *}\end{array}$ & $\begin{array}{l}0.349 \\
(3.12)^{* * *}\end{array}$ & $\begin{array}{l}0.347 \\
(3.09)^{* * *}\end{array}$ & $\begin{array}{l}0.332 \\
(2.97)^{* * *}\end{array}$ & $\begin{array}{l}0.309 \\
(2.72)^{* * *}\end{array}$ \\
\hline Equity Ratio(07-08) x Crisis 2009 & $\begin{array}{l}0.346 \\
(2.37)^{* *}\end{array}$ & $\begin{array}{l}0.322 \\
(2.24)^{* *}\end{array}$ & $\begin{array}{l}0.302 \\
(2.10)^{* *}\end{array}$ & $\begin{array}{l}0.321 \\
(2.23)^{* *}\end{array}$ & $\begin{array}{l}0.332 \\
(2.24)^{* *}\end{array}$ \\
\hline Liquidity Ratio(07-08) x Crisis 2008 & $\begin{array}{l}0.360 \\
(4.33)^{* * *}\end{array}$ & $\begin{array}{l}0.358 \\
(4.32)^{* * *}\end{array}$ & $\begin{array}{l}0.355 \\
(4.26)^{* * *}\end{array}$ & $\begin{array}{l}0.368 \\
(4.42)^{* * *}\end{array}$ & $\begin{array}{l}0.360 \\
(4.29)^{* * *}\end{array}$ \\
\hline Liquidity Ratio(07-08) $\times$ Crisis 2009 & $\begin{array}{l}0.147 \\
(1.71)^{*}\end{array}$ & $\begin{array}{l}0.137 \\
(1.58)\end{array}$ & $\begin{array}{l}0.127 \\
(1.47)\end{array}$ & $\begin{array}{l}0.110 \\
(1.26)\end{array}$ & $\begin{array}{l}0.120 \\
(1.39)\end{array}$ \\
\hline Bank FE & Y & Y & Y & Y & Y \\
\hline Country $x$ Year FE & Y & Y & Y & Y & Y \\
\hline R-squared & 0.59 & 0.59 & 0.59 & 0.59 & 0.60 \\
\hline \# observations & 4,769 & 4,823 & 4,807 & 4,769 & 4,699 \\
\hline
\end{tabular}

Notes: This table presents the results of regressions with parent financial characteristics. Parent Characteristics include deposit funding (total customer deposit to total liabilities), size (log of total assets), equity (equity to total assets ratio), and liquidity (liquid assets to total assets ratio). These parent characteristics are based on their average value of 2007 and 2008. Robust standard errors of coefficient estimates are reported in parentheses and $* * *, * *$ and $*$ indicate the $1 \%, 5 \%$, and $10 \%$ level of significance, respectively. 
Table 8: Regressions with Parent and Affiliate Characteristics

\begin{tabular}{|c|c|c|c|}
\hline & All sample & $\begin{array}{l}\text { Excluding for } \\
\text { no parent eo }\end{array}$ & $\begin{array}{l}\text { banks with } \\
\text { nformation }\end{array}$ \\
\hline & (1) & (2) & (3) \\
\hline Foreign $\times$ Crisis 2008 & $\begin{array}{l}0.150 \\
(2.48)^{* *}\end{array}$ & $\begin{array}{l}0.180 \\
(2.72)^{* * *}\end{array}$ & $\begin{array}{l}0.183 \\
(2.74)^{* * *}\end{array}$ \\
\hline Foreign $\times$ Crisis 2009 & $\begin{array}{l}-0.152 \\
(2.38)^{* *}\end{array}$ & $\begin{array}{l}-0.141 \\
(2.07)^{* *}\end{array}$ & $\begin{array}{l}-0.172 \\
(2.50)^{* *}\end{array}$ \\
\hline Government x Crisis 2008 & $\begin{array}{l}0.134 \\
(5.40)^{* * *}\end{array}$ & $\begin{array}{l}0.133 \\
(5.30)^{* * *}\end{array}$ & $\begin{array}{l}0.133 \\
(5.30)^{* * *}\end{array}$ \\
\hline Government x Crisis 2009 & $\begin{array}{l}0.114 \\
(4.71)^{* * *}\end{array}$ & $\begin{array}{l}0.111 \\
(4.53)^{* * *}\end{array}$ & $\begin{array}{l}0.110 \\
(4.51)^{* * *}\end{array}$ \\
\hline Foreign x Crisis 2008 x Parent Equity Ratio(07_08) & & & $\begin{array}{l}-0.065 \\
(0.30)\end{array}$ \\
\hline Foreign x Crisis 2009 x Parent Equity Ratio(07_08) & & & $\begin{array}{l}0.621 \\
(2.61)^{* * *}\end{array}$ \\
\hline Foreign x Crisis 2008 x Deposit Funding Ratio(07_08) & $\begin{array}{l}-0.075 \\
(0.95)\end{array}$ & $\begin{array}{l}-0.109 \\
(1.26)\end{array}$ & $\begin{array}{l}-0.107 \\
(1.23)\end{array}$ \\
\hline Foreign x Crisis 2009 x Deposit Funding Ratio(07_08) & $\begin{array}{l}0.158 \\
(1.90)^{*}\end{array}$ & $\begin{array}{l}0.133 \\
(1.49)\end{array}$ & $\begin{array}{l}0.113 \\
(1.26)\end{array}$ \\
\hline Deposit Funding Ratio(07_08) $\times$ Crisis 2008 & $\begin{array}{l}0.140 \\
(2.53)^{* *}\end{array}$ & $\begin{array}{l}0.136 \\
(2.45)^{* *}\end{array}$ & $\begin{array}{l}0.136 \\
(2.45)^{* *}\end{array}$ \\
\hline Deposit Funding Ratio(07_08) x Crisis 2009 & $\begin{array}{l}0.089 \\
(1.63)\end{array}$ & $\begin{array}{l}0.082 \\
(1.47)\end{array}$ & $\begin{array}{l}0.082 \\
(1.49)\end{array}$ \\
\hline Size $_{\left(07 \_08\right)} \times$ Crisis 2008 & $\begin{array}{l}-0.002 \\
(0.33)\end{array}$ & $\begin{array}{l}-0.002 \\
(0.33)\end{array}$ & $\begin{array}{l}-0.002 \\
(0.33)\end{array}$ \\
\hline Size $_{\left(07 \_08\right)} \times$ Crisis 2009 & $\begin{array}{l}0.001 \\
(0.12)\end{array}$ & $\begin{array}{l}0.003 \\
(0.41)\end{array}$ & $\begin{array}{l}0.004 \\
(0.49)\end{array}$ \\
\hline Equity Ratio(07_08) x Crisis 2008 & $\begin{array}{l}0.351 \\
(2.86)^{* * *}\end{array}$ & $\begin{array}{l}0.357 \\
(3.20)^{* * *}\end{array}$ & $\begin{array}{l}0.360 \\
(3.21)^{* * *}\end{array}$ \\
\hline Equity Ratio(07_08) x Crisis 2009 & $\begin{array}{l}0.291 \\
(2.18)^{* *}\end{array}$ & $\begin{array}{l}0.302 \\
(2.16)^{* *}\end{array}$ & $\begin{array}{l}0.290 \\
(2.07)^{* *}\end{array}$ \\
\hline Liquidity Ratio(07_08) x Crisis 2008 & $\begin{array}{l}0.327 \\
(3.99)^{* * *}\end{array}$ & $\begin{array}{l}0.363 \\
(4.36)^{* * *}\end{array}$ & $\begin{array}{l}0.364 \\
(4.36)^{* * *}\end{array}$ \\
\hline Liquidity Ratio(07_08) x Crisis 2009 & $\begin{array}{l}0.105 \\
(1.22)\end{array}$ & $\begin{array}{l}0.118 \\
(1.35)\end{array}$ & $\begin{array}{l}0.114 \\
(1.32)\end{array}$ \\
\hline Bank FE & Y & Y & Y \\
\hline Country x Year FE & Y & Y & Y \\
\hline R-squared & 0.59 & 0.59 & 0.59 \\
\hline \# observations & 5,167 & 4,807 & 4,807 \\
\hline
\end{tabular}

Notes: This table shows the results of regressions with equity ratio of parent banks and deposit funding ratio of foreign affiliates to compare the effect of two variables more in detail. Column (1) includes all samples, but the sample used in columns (2) and (3) excludes those foreign banks with no equity information of their parent banks. Robust standard errors of coefficient estimates are reported in parentheses and $* * *, * *$ and * indicate the $1 \%, 5 \%$, and $10 \%$ level of significance, respectively. 


\section{Conclusions and Policy Recommendations}

This paper examined the behavior of foreign banks during the global crisis. In particular, we explored the role of bank and parent financial characteristics as well as the impact of parent origin and geographic reach on foreign banks' credit growth.

Consistent with other studies, we find that foreign banks curtailed credit more than domestic banks at the height of the financial crisis in 2009. This result holds even after controlling for bank characteristics, as well as changing macroeconomic conditions in the host countries. Moreover, we find that foreign banks' credit growth dropped during the crisis even when compared directly to private domestic banks. This is an important distinction as government-owned banks operate under different objective functions and their risk appetite is less pro-cyclical than that of private banks (foreign or domestic). In fact, in contrast to results in previous studies with smaller samples, we find that government banks played a similar countercyclical role in all regions.

Although much has been discussed about the contraction of foreign bank credit growth in Eastern Europe, we find that the drop in credit growth among foreign banks was quite uniform. With the exception of foreign banks in countries that participated in the Vienna Initiative and to some extent Former Soviet Union countries, we observe no significant difference in the behavior of foreign banks across host regions.

Whether foreign banks have regional or global operations did not seem to influence their lending behavior. However, there is some evidence that the geographic origin of the parent does matter. US banks in particular seem to have retrenched their lending less than foreign banks from other regions, perhaps because the crisis that started in the US in 2007 was subsiding by 2009 and because US banks received a lot of liquidity and capital support from US regulators during the crisis years.

Interestingly, we do not find any evidence that affiliate importance influenced foreign bank credit behavior. Foreign operations that were relatively important for the group given its size or profitability did not curtail credit by less than other foreign banks. 
The funding structure of the foreign affiliate appears to have some influence on the behavior of foreign banks. Foreign affiliates with higher deposit base, and, hence, lower reliance on wholesale funding, curtailed credit by less than other foreign banks. However, a foreign ownership effect persisted that was not explained by differences in funding structure. When excluding from the sample foreign banks that did not have a financial sector parent, we found that the positive effect of lower reliance on wholesale funding disappeared for foreign banks. One possible explanation is that foreign banks that did not belong to a banking group were more dependent on money market funding than foreign banks belonging to a banking group, which were more likely to rely on parent funding. One thing we could not explicitly control for given data limitations is the reliance of foreign banks in cross-border (foreign currency) funding and whether this helped to explain their behavior.

We find that the financial characteristics of the parent, in particular parent capitalization, help explain foreign bank behavior during the global crisis. Foreign bank affiliates with well capitalized parents contracted credit by less than other foreign banks and the impact of foreign ownership itself disappeared when controlling for parent characteristics.

These results suggest that the increased globalization of banking systems may have had unintended consequences. Foreign bank ownership was promoted as a way to improve efficiency and resilience of banking sectors in the face of domestic shocks. In El Salvador, for example, all commercial banks became foreign-owned. However, the experience during the recent global financial crisis shows that foreign bank ownership increases the vulnerability of financial sectors to external shocks that affect parent companies of banks operating cross-border. Thus, to increase the resilience to a variety of shocks, it appears that a more diversified banking sector structure in terms of ownership could be desirable. Of course, the optimal structure would depend on the mix of shocks to which the banking sector is exposed to, with a larger share of foreign bank ownership being more appropriate for countries for which the most frequent shocks are domestic in nature. To the extent that increased globalization increases the frequency of external shocks, the optimal financial sector structure would evolve over time. 
Our results also indicate that government bank ownership can help (at least in the short-term) mitigate the impact of external shocks. While foreign banks are particularly affected by them, domestic banks are not immune to their effect and they curtail credit as well in the midst of increased risk aversion. As the public sector is more risk neutral through- the- cycle, government banks in countries with a sound fiscal position can play a countercyclical role. However, past experience with public banks points to substantial risks of banking sector government ownership. To ensure that credit risks are appropriately priced by public banks operating counter-cyclically and that they are professionally managed, good governance and state-of-the-art risk management are key. In the absence of those conditions, public sector bank ownership would be counterproductive.

Altering the ownership structure of the banking system is not always a viable proposition and, even when it is, it is likely to take time. ${ }^{16)}$ Macroprudential financial sector regulation can mitigate the effects of external shocks on credit developments. To the extent that reliance on wholesale funding prompts foreign banks to cut credit faster than domestic banks (perhaps associated to the fact that most of these funds are cross-border), stable funding ratios as established by Basel III but with differential treatment of cross-border versus other wholesale funding appear sensible. So do Basel III guidelines for banks to increase the quality and quantity of their capital base.

16) Some countries such as El Salvador and Mexico are pursuing a banking sector diversification structure by promoting entrance of niche institutions, regularizing credit cooperatives, and increasing public banks share in the financial system. 


\section{References}

Cetorelli, N., and L.S. Goldberg (2011), "Global Banks and International Shock Transmission: Evidence from the Crisis," IMF Economic Review, 59, pp. 41-76.

Claessens, S., and N. van Horen (2013), "Foreign Banks: Trends, Impact, and Financial Stability," Journal of Money, Credit and Banking, Forthcoming.

Cull, R., and M.S. Martinez Peria (2011), "Foreign Bank Participation in Developing Countries: What Do We Know about the Drivers and Consequences of this Phenomenon," Forthcoming in Gerard Caprio (Ed), Encyclopedia of Financial Globalization, Elsevier Amsterdam.

Cull, R., and M.S. Martinez Peria (2013), "Bank Ownership and Lending Patterns during the 2008-2009 Financial Crisis: Evidence from Latin America and Eastern Europe," Journal of Banking and Finance, Forthcoming.

Crystal, J., G. Dages, and L. Goldberg (2001), "Does Foreign Ownership Contribute to Sounder Banks in Emerging Markets? The Latin American Experience," in Open Doors: Foreign Participation in Financial Systems in Developing Countries, April 19-21.

Crystal, J., G. Dages, and L. Goldberg (2002), "Has Foreign Bank Entry Led to Sounder Banks in Latin America?" Current Issues in Economic and Finance, 8(1), Federal Reserve Bank of New York.

De Haas, R., Y. Korniyenko, E. Loukoianova, and A. Pivovarsk (2012), "Foreign Banks during the crisis: Sinners or Saints?” European Bank for Reconstruction and Development Working Paper, 143.

De Haas, R., and N. van Horen (2012), "International Shock Transmission after the Lehman Brothers Collapse: Evidence from Syndicated Lending," American Economic Review: Paper and Proceedings, 102(3), pp. 231-237.

De Haas, R., and N. van Horen (2013), "Running for the Exit? International Bank Lending during a Financial Crisis," Review of Financial Studies, 26(1), pp. 244-285.

De Haas, R., and I. van Lelyveld (2006), "Foreign Banks and Credit Stability 
in Central and Eastern Europe. A Panel Data Analysis," Journal of Banking and Finance, 30(7), pp. 1927-1952.

De Haas, R., and I. van Lelyveld (2013), "Multinational Banks and the Global Financial Crisis: Weathering the Perfect Storm?” Journal of Money, Credit and Banking, Forthcoming.

Detragiache, E., and P. Gupta (2006), "Foreign banks in emerging market crises: Evidence from Malaysia,” Journal of Financial Stability, 2(3), pp. 217-242.

Fungácová, Z., R. Herrala, and L. Weill (2013), "The Influence of Bank Ownership on Credit Supply: Evidence from the Recent Financial Crisis," Emerging Markets Review, 15, pp. 136-147.

Giannetti, M., and L. Laeven (2012), "The Flight Home Effect: Evidence from the Syndicated Loan Market during Financial Crises," Journal of Financial Economics, 104(1), pp. 23-43.

Herrmann, R., and D. Mihaljek (2010), "The Determinants of Cross-Border Bank Flows to Emerging Markets: New Empirical Evidence on the Spread of Financial Crises," Deutsche Bunderbank and BIS working paper.

McGuire, P., and N. Tarashev (2008), "Bank Health and Lending to Emerging Markets," BIS Quarterly Review, December, pp. 67-80.

Peek, J., and E. S. Rosengren (2000), "Collateral Damage: Effects of the Japanese Bank Crisis on Real Activity in the United States," American Economic Review, 90, pp. $30-45$.

Peek, J., and E. S. Rosengren (2000), "Implications of the Globalization of the Banking Sector: The Latin American Experience," Federal Reserve Bank of Boston New England Economic Review, September-October, pp. 45-62.

Schnabl, P. (2012), "The International Transmission of Bank Liquidity Shocks: Evidence from an Emerging Market," Journal of Finance, 67(3), pp. 897-932. 


\section{Appendix}

Table A.1: List of Parent Institutions

\begin{tabular}{|c|c|c|c|c|c|}
\hline Country & Parent Institutions & $F G G$ & Country & Parent Institutions & FGG \\
\hline \multicolumn{6}{|c|}{ Parent Origin: Europe } \\
\hline \multirow{13}{*}{ Austria } & BAWAG Bank & & \multirow{2}{*}{ Kazakhstan } & BTA Bank & \\
\hline & BKS Bank AG & & & Visor Group & \\
\hline & ERSTE GROUP BANK AG & & Latvia & Latvian Privatization Agency & \\
\hline & $\begin{array}{l}\text { Grazer Wechselseitige } \\
\text { Versicherung AG }\end{array}$ & & \multirow{2}{*}{ Liechtenstein } & KSN Foundation & \\
\hline & $\begin{array}{l}\text { Hypo Alpe-Adria-Bank } \\
\text { International AG }\end{array}$ & & & RÉSEAU FINANCIER & \\
\hline & Makarios (MG) Holdings GMBH & & Lithuania & Bankas Snoras & \\
\hline & Meinl Bank & & \multirow{8}{*}{ Netherlands } & ABN AMRO & $x$ \\
\hline & Porsche Holding & & & Caspian Group & \\
\hline & $\begin{array}{l}\text { RAIFFEISEN LANDESBANKEN } \\
\text { HOLDING }\end{array}$ & & & Credit Europe Bank & \\
\hline & $\begin{array}{l}\text { Steiermärkische Bank und } \\
\text { Sparkassen AG }\end{array}$ & & & Demir-Halk Bank & \\
\hline & $\begin{array}{l}\text { Vienna Capital Partners } \\
\text { Unternehmensberatungs AG }\end{array}$ & & & Fiba Holding AS & \\
\hline & VOLKSBANK & & & ING Group & $x$ \\
\hline & Wuestenrot & & & PPF Group N.V. & \\
\hline \multirow{4}{*}{ Belgium } & AXA HOLDINGS BELGIUM & & & Rabobank & $x$ \\
\hline & Dexia & & Norway & DNB Bank ASA & \\
\hline & Fortis Bank & & \multirow{2}{*}{ Poland } & Kredyt Bank & \\
\hline & KBC Bank & & & $\begin{array}{l}\text { Powszechna Kasa } \\
\text { Oszczednosci Bank }\end{array}$ & \\
\hline \multirow{4}{*}{ Cyprus } & $\begin{array}{l}\text { Cyprus Popular Bank Public } \\
\text { Co Ltd }\end{array}$ & & \multirow{5}{*}{ Portugal } & Banco Comercial Português SA & \\
\hline & Kaluma Holdings Limited & & & Banif Group & \\
\hline & Marfin Popular Bank & & & BPN & \\
\hline & Sharp Arrow Holdings & & & $\begin{array}{l}\text { Millenium Banco Comercial } \\
\text { Português }\end{array}$ & \\
\hline $\begin{array}{l}\text { Czech } \\
\text { Republic }\end{array}$ & $\begin{array}{l}\text { Ceskoslovenska Obchodni } \\
\text { Banka }\end{array}$ & & & Tecnicredito SGPS & \\
\hline Denmark & Danske Bank & & \multirow{8}{*}{ Russia } & Alfa-Bank & \\
\hline Finland & Sampo Bank & & & Bank of Moscow & \\
\hline \multirow{3}{*}{ France } & BNP Paribas & $x$ & & Commercial bank Petrocommerce & \\
\hline & Crédit Agricole & $x$ & & Gazprom & \\
\hline & Société Générale & $x$ & & Lukoil & \\
\hline Georgia & Bank of Georgia & & & Rosbank & \\
\hline \multirow[b]{2}{*}{ Germany } & Allianz & $x$ & & Sberbank of Russia & \\
\hline & $\begin{array}{l}\text { Bayerische Hypo und Vereins } \\
\text { Bank AG }\end{array}$ & & & SMP Bank & \\
\hline
\end{tabular}




\begin{tabular}{|c|c|c|c|c|c|}
\hline Country & Parent Institutions & FGG & Country & Parent Institutions & FGG \\
\hline \multirow{11}{*}{ Germany } & Bayerische Landesbank & & \multirow{5}{*}{ Russia } & Vnesheconombank & \\
\hline & BHW Holding & & & TDA HOLDING LIMITED & \\
\hline & Commerzbank & $x$ & & TRANSCAPITAL LLC & \\
\hline & Daimler AG & & & VEB & \\
\hline & Deutsche Bank & $x$ & & VTB Bank & \\
\hline & DZ BANK AG & & Serbia & Komercijalna Banka & \\
\hline & $\begin{array}{l}\text { Landesbank } \\
\text { Baden-Württemberg }\end{array}$ & & Slovakia & TECHNO PLUS & \\
\hline & NORD/LB & & \multirow[b]{2}{*}{ Slovenia } & NLB DD & \\
\hline & ProCredit Holding & & & $\begin{array}{l}\text { Slovenian Nova Ljubljanska } \\
\text { Banka }\end{array}$ & \\
\hline & Volkswagen Bank & & \multirow{3}{*}{ Spain } & Banco Santander & $x$ \\
\hline & WestLB & & & BBVA & $x$ \\
\hline \multirow{7}{*}{ Greece } & $\begin{array}{l}\text { Agricultural Bank of Greece } \\
\text { SA }\end{array}$ & & & Grupo IF & \\
\hline & Alpha Bank & & \multirow{4}{*}{ Sweden } & Nordea Bank AB & \\
\hline & EFG Eurobank & & & $\begin{array}{l}\text { Skandinaviska Enskilda } \\
\text { Banken } A B\end{array}$ & \\
\hline & Emporiki Bank of Greece & & & Swedbank & \\
\hline & MARFIN EGNATIA BANK SA & & & VOLVO HOLDING SVERIGE AB & \\
\hline & National Bank of Greece & & \multirow{6}{*}{ Switzerland } & Banque Heritage & \\
\hline & Piraeus Bank & & & $\begin{array}{l}\text { EHH Eastern Hemisphere } \\
\text { Holding }\end{array}$ & \\
\hline Hungary & OTP Bank & & & $\begin{array}{l}\text { ICB Financial Group Holdings } \\
\text { AG }\end{array}$ & \\
\hline Iceland & Milestone EHF & & & SIRMAKES VARTAN & \\
\hline \multirow{2}{*}{ Ireland } & $\begin{array}{l}\text { Abbeyfield Financial Holding } \\
\text { Limited }\end{array}$ & & & Swiss Zepter International & \\
\hline & Allied Irish Banks & & & UBS & $x$ \\
\hline \multirow{6}{*}{ Italy } & Banco Popolare Soc Coop & & \multirow{4}{*}{ Turkey } & Calik Financial Services & \\
\hline & FGA CAPITAL SPA & & & Finansbank Turkey & \\
\hline & Intesa Sanpaolo & $x$ & & Kent Bank & \\
\hline & Trieste & & & T C Ziraat Bankasi & \\
\hline & UniCredit Group & & \multirow{2}{*}{ UK } & HSBC HOLDINGS PLC & $x$ \\
\hline & Veneto Banca Scpa & & & LLOYDS BANKING GROUP PLC & \\
\hline \multirow{3}{*}{ UK } & London international Bank Ltd & & \multirow{3}{*}{ Ukraine } & Bank PIVDENNYI & \\
\hline & Royal Bank of Scotland & $x$ & & PrivatBank & \\
\hline & STANDARD CHARTERED PLC & $x$ & & Ukrprombank & \\
\hline & & arent $C$ & gin: US & & \\
\hline \multirow{3}{*}{ US } & $\begin{array}{l}\text { ADVANCED GLOBAL } \\
\text { INVESTMENTS LLC }\end{array}$ & & \multirow{3}{*}{ US } & CARGILL & \\
\hline & Advent International & & & CITIGROUP & $x$ \\
\hline & AIG & $\mathrm{x}$ & & Deere \& Company & \\
\hline
\end{tabular}




\begin{tabular}{|c|c|c|c|c|c|}
\hline Country & Parent Institutions & FGG & Country & Parent Institutions & FGG \\
\hline \multirow{6}{*}{ US } & $\begin{array}{l}\text { Albanian-American Enterprise } \\
\text { Fund }\end{array}$ & & \multirow{6}{*}{ US } & General Electric Capital & $x$ \\
\hline & Ally Financial Inc & & & JP Morgan Chase & $x$ \\
\hline & $\begin{array}{l}\text { AMERICAN EXPRESS } \\
\text { COMPANY }\end{array}$ & $x$ & & Lone Star & \\
\hline & Bank of America NA & $x$ & & New Century Holding Fund & \\
\hline & BankBoston & & & $\begin{array}{l}\text { OPPORTUNITY INVESTMENTS } \\
\text { INC }\end{array}$ & \\
\hline & $\begin{array}{l}\text { Bulgarian American Enterprise } \\
\text { Fund }\end{array}$ & & & & \\
\hline \multicolumn{6}{|c|}{ Parent Origin: Other } \\
\hline Argentina & Banco de la Nación Argentina & & Jordan & Arab Bank & \\
\hline \multirow{2}{*}{ Australia } & $\begin{array}{l}\text { Australia and New Zealand } \\
\text { Banking Group }\end{array}$ & & \multirow{7}{*}{ Korea } & Chohung Bank & \\
\hline & $\begin{array}{l}\text { Commonwealth Bank of } \\
\text { Australia }\end{array}$ & & & Hana Bank & \\
\hline \multirow[b]{2}{*}{ Bahrain } & Arab Banking Corporation & $x$ & & Hanwha Securities Co & \\
\hline & TAIB Bank BSC & & & $\begin{array}{l}\text { Korea Deposit Insurance } \\
\text { CorpKorea }\end{array}$ & \\
\hline \multirow{3}{*}{ Brazil } & Banco Bradesco SA & & & Korea Development Bank & \\
\hline & Banco do Brasil SA & & & Korea Exchange Bank & \\
\hline & Itau Unibanco Holding SA & & & Shinhan Financial Group & \\
\hline \multirow{2}{*}{$\begin{array}{l}\text { British } \\
\text { Virgin } \\
\text { Islands }\end{array}$} & CHRYSTIE MANAGEMENT INC & & \multirow[b]{2}{*}{ Lebanon } & BYBLOS BANK S.A.L. & \\
\hline & $\begin{array}{l}\text { Trimont Investment } \\
\text { Corporation }\end{array}$ & & & FRANSAHOLDING S.A. & \\
\hline \multirow{4}{*}{ Canada } & $\begin{array}{l}\text { BANK OF NOVA SCOTIA (THE) } \\
\text { - SCOTIABANK }\end{array}$ & $x$ & \multirow{5}{*}{ Malaysia } & $\begin{array}{l}\text { CIMB GROUP HOLDINGS } \\
\text { BERHAD }\end{array}$ & \\
\hline & $\begin{array}{l}\text { CANADIAN IMPERIAL BANK } \\
\text { OF COMMERCE }\end{array}$ & & & ICB Financial Group & \\
\hline & Portland Holdings Inc & & & Khazanah Nasional Berhad & \\
\hline & $\begin{array}{l}\text { ROYAL BANK OF CANADA } \\
\text { RBC }\end{array}$ & $x$ & & Malayan Banking Berhad & \\
\hline \multirow{2}{*}{ Chile } & Group Falabella & & & Public Bank Berhad & \\
\hline & Grupo Altas Cumbres & & Mexico & Grupo Elektra & \\
\hline \multirow[b]{2}{*}{ China } & Bank of China & & \multirow[b]{2}{*}{ Panama } & Corporacion UBC Internacional & \\
\hline & $\begin{array}{l}\text { Industrial \& Commercial Bank } \\
\text { of China Limited }\end{array}$ & & & GRUPO ASSA SA & \\
\hline \multirow{5}{*}{ Colombia } & Bancafe & & & Grupo Banistmo & \\
\hline & BANCO DAVIVIENDA & & Panama & Grupo Financiero Uno & \\
\hline & Bancolombia & & & $\begin{array}{l}\text { Promerica Financial } \\
\text { Corporation }\end{array}$ & \\
\hline & GRUPO AVAL ACCIONE & & \multirow{2}{*}{ Peru } & CREDICORP LTD & \\
\hline & Helm Bank & & & IFH PERU LTD & \\
\hline \multirow{3}{*}{ Costa Rica } & BAC Credomatic Group & & Saudi Arabia & Islamic Development Bank & \\
\hline & Banco de Costa Rica & & \multirow{2}{*}{ Singapore } & DBS GROUP HOLDINGS LTD & \\
\hline & CORPORACION BCT, SA & & & Ministry of Finance of & \\
\hline
\end{tabular}




\begin{tabular}{|c|c|c|c|c|c|}
\hline Country & Parent Institutions & FGG & Country & Parent Institutions & FGG \\
\hline \multirow[b]{2}{*}{ Costa Rica } & & & \multirow{4}{*}{ Singapore } & Singapore & \\
\hline & LAFISE FINANCIAL GROUP & & & $\begin{array}{l}\text { Oversea-Chinese Banking } \\
\text { Corp Ltd }\end{array}$ & \\
\hline \multirow{2}{*}{$\begin{array}{l}\text { Dominica } \\
\text { Rep. }\end{array}$} & CENTRO FINANCIERO SA & & & $\begin{array}{l}\text { Singapore Banking } \\
\text { Corporation Ltd }\end{array}$ & \\
\hline & GRUPO POPULAR SA & & & UNITED OVERSEAS BANK & \\
\hline Ecuador & Banco Pichincha & & \multirow[b]{2}{*}{ South Africa } & Liberty Investment Holding & \\
\hline El Salvador & $\begin{array}{l}\text { Inversiones Financieras Banco } \\
\text { Agricola SA }\end{array}$ & & & $\begin{array}{l}\text { STANDARD BANK GROUP } \\
\text { LIMITED }\end{array}$ & \\
\hline \multirow[b]{2}{*}{ Guatemala } & Banco Industrial & & \multirow{4}{*}{ Taiwan } & Cathay United Bank & \\
\hline & $\begin{array}{l}\text { Grupo Financiero G\&T } \\
\text { Continental }\end{array}$ & & & $\begin{array}{l}\text { CHINATRUST FINANCIAL } \\
\text { HOLDING }\end{array}$ & \\
\hline Honduras & Inversiones Continental SA & & & First Financial Holding & \\
\hline \multirow{3}{*}{ Israel } & BANK HAPOALIM BM & & & MEGA FINANCIAL HOLDING & \\
\hline & BANK LEUMI LE ISRAEL BM & & \multirow{2}{*}{ Thailand } & $\begin{array}{l}\text { BANGKOK BANK PUBLIC } \\
\text { COMPANY }\end{array}$ & \\
\hline & ISRAEL DISCOUNT BANK LTD & & & Siam Commercial Bank & \\
\hline \multirow{6}{*}{ Japan } & ACOM CO, LTD & & \multirow{2}{*}{$\begin{array}{l}\text { Trinidad and } \\
\text { Tobago }\end{array}$} & \multirow{2}{*}{$\begin{array}{l}\text { RBTT Financial Holdings } \\
\text { Limited }\end{array}$} & \\
\hline & Bank of Tokyo-Mitsubishi & $x$ & & & \\
\hline & MIZUHO FINANCIAL GROUP & & \multirow{2}{*}{ Uruguay } & $\begin{array}{l}\text { Banco de la República Oriental } \\
\text { del Uruguay }\end{array}$ & \\
\hline & Resona Bank Limited & & & LANDY SA & \\
\hline & $\begin{array}{l}\text { SUMITOMO MITSUI FINANCIAL } \\
\text { GROUP, INC }\end{array}$ & $x$ & \multirow{2}{*}{ Venezuela } & Banesco & \\
\hline & $\begin{array}{l}\text { TOYOTA MOTOR } \\
\text { CORPORATION }\end{array}$ & & & Mercantil Servicios Financieros & \\
\hline
\end{tabular}

Notes: This table presents the name of foreign parent institutions of foreign affiliates in our sample and their country of origin by regions (Europe, US, and other regions) during the sample period from 2005 to 2009. FGG indicates that the parent belongs to Foreign Global Groups that operate their subsidiaries not only within their region of origin but also in other regions. Some of parent institutions are non-bank institutions, and parent banks that are not FGG are categorized as regional banks. 
Table A.2: Descriptive Statistics

\begin{tabular}{|c|c|c|c|c|c|c|}
\hline & Variable Name & Description & Mean & $\begin{array}{l}\text { Std. } \\
\text { Dev. }\end{array}$ & Min & $\operatorname{Max}$ \\
\hline $\begin{array}{l}\text { Dependent } \\
\text { Variable }\end{array}$ & $\begin{array}{l}\text { Real growth rate } \\
\text { of gross loans }\end{array}$ & $\begin{array}{l}\text { Log difference in total real gross } \\
\text { loans }\end{array}$ & 0.212 & 0.297 & -0.664 & 1.491 \\
\hline \multirow{6}{*}{$\begin{array}{c}\text { Bank } \\
\text { Characteristics }\end{array}$} & Government & $\begin{array}{l}1 \text { if bank is } 50 \text { percent or more } \\
\text { owned by central or local } \\
\text { governments }\end{array}$ & 0.122 & 0.327 & 0 & 1 \\
\hline & Foreign & $\begin{array}{l}1 \text { if bank is } 50 \text { percent or more } \\
\text { owned by foreigners }\end{array}$ & 0.426 & 0.495 & 0 & 1 \\
\hline & $\begin{array}{l}\text { Deposit funding } \\
\text { ratio }\end{array}$ & $\begin{array}{l}\text { Total customer deposits / total } \\
\text { liabilities }\end{array}$ & 0.654 & 0.250 & 0 & 0.998 \\
\hline & Size & $\begin{array}{l}\text { Log of real total assets in millions } \\
\text { of US\$ }\end{array}$ & 6.744 & 1.942 & -2.578 & 12.269 \\
\hline & Equity ratio & Equity / total assets & 0.150 & 0.120 & 0.003 & 0.992 \\
\hline & Liquidity ratio & Liquid assets / total assets & 0.247 & 0.155 & 0.0003 & 0.999 \\
\hline \multirow{2}{*}{$\begin{array}{l}\text { Crisis Dummy } \\
\text { Variables }\end{array}$} & Crisis2008 & 1 if year is 2008 & 0.216 & 0.411 & 0 & 1 \\
\hline & Crisis2009 & 1 if year is 2009 & 0.203 & 0.402 & 0 & 1 \\
\hline \multirow{4}{*}{$\begin{array}{l}\text { Foreign } \\
\text { Affiliate } \\
\text { Regional } \\
\text { Dummy } \\
\text { Variables }\end{array}$} & ECA VI & $\begin{array}{l}1 \text { if country in ECA is participating } \\
\text { Vienna Initiative }\end{array}$ & 0.102 & 0.302 & 0 & 1 \\
\hline & ECA FSU & $\begin{array}{l}1 \text { if country in ECA is classified as } \\
\text { Former Soviet Union }\end{array}$ & 0.129 & 0.335 & 0 & 1 \\
\hline & ECA Europe & $\begin{array}{l}1 \text { for the rest of ECA countries in } \\
\text { the sample }\end{array}$ & 0.174 & 0.379 & 0 & 1 \\
\hline & EAP & 1 if country is in EAP region & 0.169 & 0.374 & 0 & 1 \\
\hline \multirow{10}{*}{$\begin{array}{c}\text { Parent } \\
\text { Characteristics }\end{array}$} & $\begin{array}{l}\text { FGG (Foreign } \\
\text { Global Groups) }\end{array}$ & $\begin{array}{l}1 \text { if parent of foreign bank is } \\
\text { classified as FGG** }\end{array}$ & 0.140 & 0.347 & 0 & 1 \\
\hline & \begin{tabular}{|l|l} 
Foreign \\
Regional
\end{tabular} & $\begin{array}{l}1 \text { if parent of foreign bank is a } \\
\text { non-FGG regional bank }\end{array}$ & 0.286 & 0.452 & 0 & 1 \\
\hline & Foreign US & $\begin{array}{l}1 \text { if parent of foreign bank is from } \\
\text { US }\end{array}$ & 0.044 & 0.206 & 0 & 1 \\
\hline & Foreign EU & $\begin{array}{l}1 \text { if parent of foreign bank is from } \\
\text { Europe }\end{array}$ & 0.266 & 0.442 & 0 & 1 \\
\hline & $\begin{array}{l}\text { Parent Deposit } \\
\text { funding ratio }\end{array}$ & $\begin{array}{l}\text { Total customer deposits of parent } \\
\text { / total liabilities of parent }\end{array}$ & 0.479 & 0.209 & 0.002 & 0.993 \\
\hline & Parent Size & $\begin{array}{l}\text { Log of real total assets of parent } \\
\text { in millions of US\$ }\end{array}$ & 12.213 & 2.208 & 3.799 & 15.111 \\
\hline & $\begin{array}{l}\text { Parent Equity } \\
\text { ratio }\end{array}$ & Parent's Equity / total assets & 0.072 & 0.053 & 0.014 & 0.707 \\
\hline & $\begin{array}{l}\text { Parent Liquidity } \\
\text { ratio }\end{array}$ & $\begin{array}{l}\text { Parent's Liquid assets / total } \\
\text { assets }\end{array}$ & 0.217 & 0.109 & 0.051 & 0.565 \\
\hline & $\begin{array}{l}\text { Total Number of } \\
\text { Banks }\end{array}$ & 1,194 & & & & \\
\hline & $\begin{array}{l}\text { Total } \\
\text { Observations }\end{array}$ & 5,167 & & & & \\
\hline
\end{tabular}

Notes: this table presents the descriptive statistics of variables used in our regression analysis.

* Bank and parent characteristics (Deposit funding ratio, Size, Equity ratio, Liquidity ratio) are based on average values between 2007 and 2008.

** Refer to Appendix table for FGG (Foreign Global Group) 


\section{$<$ Abstract in Korean $>$}

\section{최문정*, Eva Gutierrez**, Maria Soledad Martinez Peria***}

본 연구는 2008-2009 글로벌 금융위기 동안 외국은행(foreign-owned)의 신용행태에 대해 살펴보았다. 이를 위해 2005-2009년 기간의 동-중부 유럽, 동아시아, 남미지역 51 개 국가의 은행 패널데이터를 사용하여 외국은행과 모은행(parent banks)의 금융 특성, 지역적 위치, 모은행의 해외진출 정도가 외국은행의 신용증가에 미치는 영향에 대해 분석하였다.

분석 결과, 금융위기의 영향이 크게 나타난 2009년, 외국은행의 신용증가율은 지역에 상관없이 국내의 민간(private), 국유(government-owned)은행에 비해 줄어들었으나, 미국에 모은행을 둔 외국은행은 다른 지역에 모은행을 둔 외국은행에 비해 신용증가율이 높은 것으로 나타났다. 모은행이 여러 지역에 진출해있는 글로벌 은행인지(global banks), 혹은 특정 지역 내에만 운영되는 지역은행(regional banks)인지 여부는 외국은행의 신용증가율에는 유의한 영향을 미치지 않은 것으로 나타났다. 그러나, 부채 대비 고객예수금비율 (deposit funding ratio) 이 높은 외국은행일수록, 모은행의 총자산 대비 자본비율 (equity to total asset ratio)이 높은 외국은행일수록 글로벌 금융위기 동안 신용증가율이 높은 것으로 나타났다. 이에 반해, 글로벌 금융위기 동안 모든 지역의 국내 국유은행은 경기완충적인(countercyclical) 신용행태를 보인 것으로 나타났다.

* 한국은행 경제연구원 국제경제연구실 전문연구원

** 세계은행(The World Bank), Finance and Private Sector Development, Lead Financial Sector Specialist *** 세계은행(The World Bank), Finance and Private Sector Development Research Group, Research Manager 